\title{
Management of the Effects of Land Use Changes on Urban Infrastructure Capacity: A Case Study of Ruaka Town, Kiambu County, Kenya
}

\author{
Dennis Abuya** Maurice Oyugi Edwin Oyaro \\ Department of Architecture and building Science-School of the Built Environment, University of Nairobi, State- \\ House Road, P.O Box 30197-00100, Nairobi-Kenya.
}

\begin{abstract}
Land use change is a major driver to the effects of climate change and other socio-economic and environmental challenges, a major challenge policy makers, planners and urban managers grapple with. Ruaka town is no exception as it faces high rapid land use change with myriad challenges on the management of the effects on urban infrastructure and aggravated by inadequate inter-agencies, coordination and collaboration. The study is an investigation of the effects of land use changes on urban infrastructure (roads, water supply, and wastewater infrastructure). It seeks to answer the drivers of land use changes and document the spatial-temporal land use changes between the years 1988 to 2019, establish their effects on infrastructure. The study establishes decline in vegetation and agriculture and rise in built -up areas which is partially contributed by urbanization and population growth in the area with major land fragmentations and land use conversions. The findings reveal encroachment of development to vegetation and riparian reserves which expose the human population to disasters and calamities in cases of climate change. Lack of approved planning policy has encouraged massive land use changes due to the ad hoc nature of planning using the development control tools which are not documented. The key drivers of land use changes deduced were good accessibility of the area, land speculation for investments, high returns from investments, demand for housing and accommodation and high population growth. The adverse effects on urban infrastructure includes pollution and contamination of water sources, traffic congestion, use of unconventional onsite waste management practices such as pit latrines and septic tanks for waste water management. The study concluded by evolving a management strategy to unravel the challenges through promotion of a sustainable and resilient urban infrastructure. The strategies emphasize on the technical, social, economic, environmental and jurisdictional dimensions.

Key Terms: County Government, Development, Land Cover, Land Use, Land, Sustainable Development, Urban Infrastructure and Urban Sprawl.
\end{abstract}

DOI: $10.7176 / \mathrm{CER} / 11-7-03$

Publication date: August $31^{\text {st }} 2019$

\section{INTRODUCTION}

Urbanization is a key factor to land use change, mainly through its transformative effects on rural areas into urban built-up areas (Lambin et al, 2001)[6]. It is estimated that more than half (55\%) of the world population lived in urban areas in the year 2018 and it is projected that $60 \%$ and $68 \%$ of the world population will be living in urban areas by the year 2030 and 2050 respectively but with a high concentration in Asia and Africa (UN, 2018) [12]. The rapid pace of urbanization has brought about rapid land use change and land cover conversions in Africa and Asia as occasioned by the fact that most parts of Africa and Asia are still predominantly rural as opposed to developed countries. Based on the current trends, the urban land cover will increase by 1.2 million $\mathrm{Km}^{2}$ by the year 2030 (UNDP, 2016) [11]. While urban areas are experiencing unprecedented land use changes, it's evident that a majority of such centers in Kenya are unprepared for urban growth and are ill-equipped to manage the resultant effects of land use changes on urban infrastructure. The strain caused by rapid urbanization and land use changes has exacerbated problems with the safety of urban infrastructure and distribution systems creating a capacity concern as evidenced by inadequate design; construction and inadequacy in its management. Policymakers equally face major challenges of handling such unprecedented urban growth because of inadequate capacity, lack of guiding policy and institutional framework to guide in the administration and development control. Equally, the weak capacity of the county governments to enforce development control has worsened the situation.

Ruaka Town in Kiambu County formerly a predominantly rural agricultural center has over the years expanded leading to land subdivisions and conversions from agricultural to residential and commercial users without a guiding framework for the transformation. This has consequently led to traffic congestion, intermittent water supply, poor liquid and solid waste management, high cases of insecurity and high disease prevalence among others. The solution to these challenges in most of the urban centres seems to be ad hoc and reactionary rather than proactive measures being put in place. Over the past years, there has been planning efforts to have all urban centres within Kiambu County have physical development plans prepared but this has not been implemented. This has 
been occasioned by inadequate coordination between institutions, lack of technical, financial capacity and political goodwill as well as negative reactions of local communities based upon previous negative experiences and numerous unmet promises leading to lack of trust in such government operations (Kenawy et al. 2017) [4]. This has led to the haphazard urban growth which raises questions on the capacity of the institutions and management strategies they use in containing these catastrophes.

The County Government of Kiambu has not lived up to the expectations of controlling urban developments. This has led to uncontrolled developments and land use changes which has resulted in negative effects on urban infrastructure. Due to the nature of densification without commensurate urban infrastructure expansion, there has been strain on the access roads which were footpaths to agricultural farms and single dwelling units, contamination of water from sunk boreholes adjacent to neighboring sanitation facilities such as pit latrines and leakages from septic tanks as the area does not have a conventional sewerage system. This has been attributed to a lack of effective management policy in place, inadequate financial support and technical capacity of the County Government to deal with the uncontrolled urban developments. Against this backdrop, large knowledge gaps exist in containing the effects of land use changes (LUC) on urban infrastructure. The evaluation brings forward limitations of the County Government to manage the effects of urban LUC on urban infrastructure yet this is imperative for sustainable urban development. Despite previous similar studies, a gap has been identified as previous studies never opted for management strategies to contain the effects of LUC on urban infrastructure with land use changeresilient urban infrastructure systems. The study, therefore, fills this gap and culminates into providing answers and recommendations on promoting land use change-resilient urban infrastructure with sustainable growth.

The goal of this study was to investigate the effects of land use changes on urban infrastructure with the aim of promoting land use change-resilient urban infrastructure with sustainable urban development.

The following objectives guided the study;

i. To document the land use changes and establish their drivers in Ruaka Town, Kiambu.

ii. To establish the effects of land use changes on existing roads, water, and wastewater infrastructure capacity in Ruaka Town, Kiambu.

iii. To evolve a management strategy to unravel the effects of land use changes on roads, water and waste water infrastructure capacity.

Ruaka town is situated within Ndenderu Ward, Kiambaa Sub-County, Kiambu County. The town is located North West of Nairobi City and is easily accessed by the Northern Bypass and Limuru Road. Ruaka is part of the larger Nairobi Metropolitan with easy access to Kiambu, Limuru, Nairobi, Thika, Kajiado, Machakos and Muranga Towns. The study area is situated between Longitude $36^{\circ} 31^{\prime} 0^{\prime \prime}$ and $37^{\circ} 15^{\prime} 0^{\prime \prime}$ East and latitudes $10^{\circ} 25^{\prime} 0^{\prime \prime}$ and $1^{\circ} 12^{\prime} 0^{\prime \prime}$ South of the Equator.

\section{Map 1: Location of Ruaka in Africa, Kenya and Kiambu County Context}

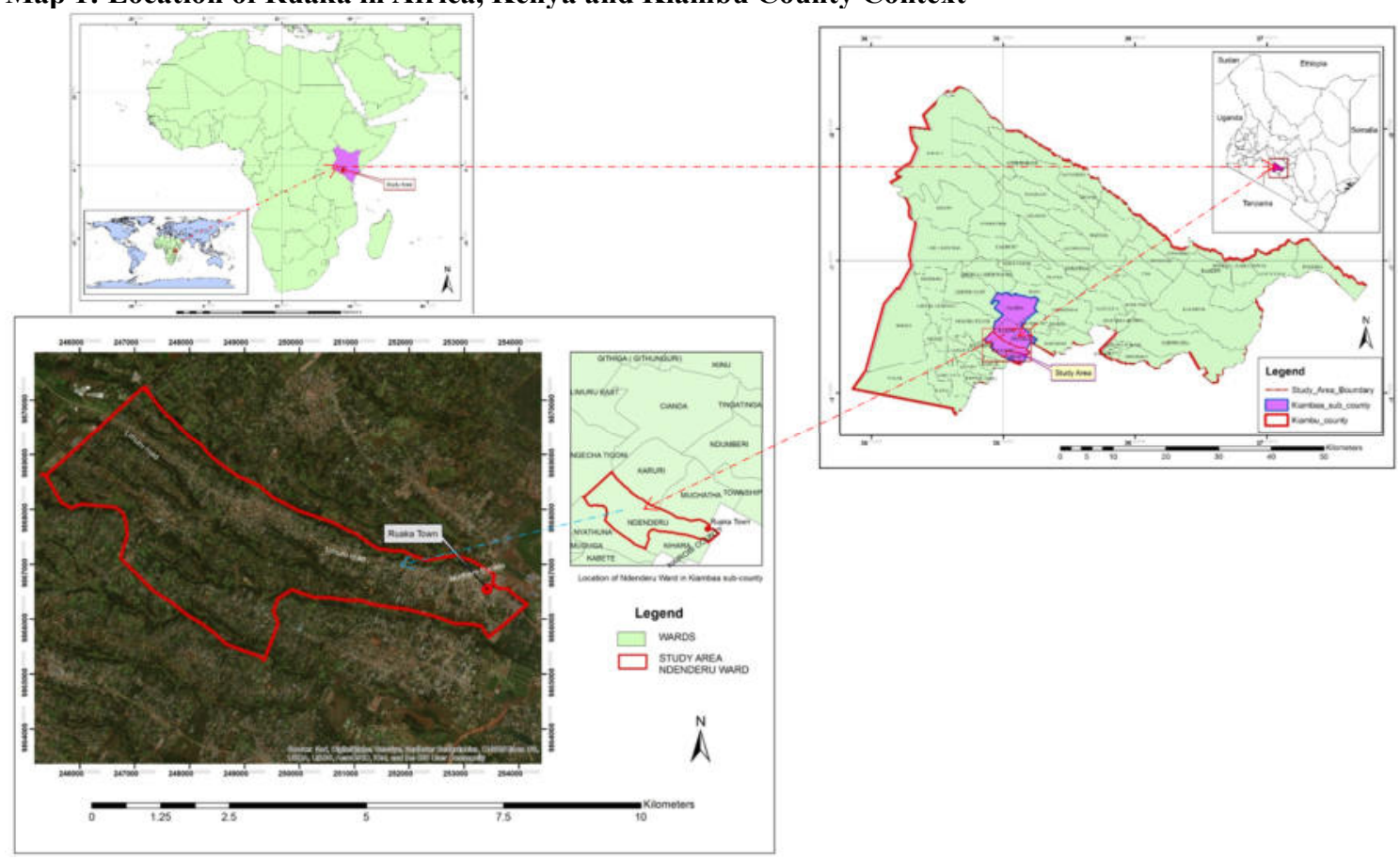

Land fragmentation with irregular shaped plots and rapid land use conversions has triggered linear 
developments patterns and trends as illustrated in Map 2 and Map 3 below.

Map 2: Built-Up Developments Trend 2019.

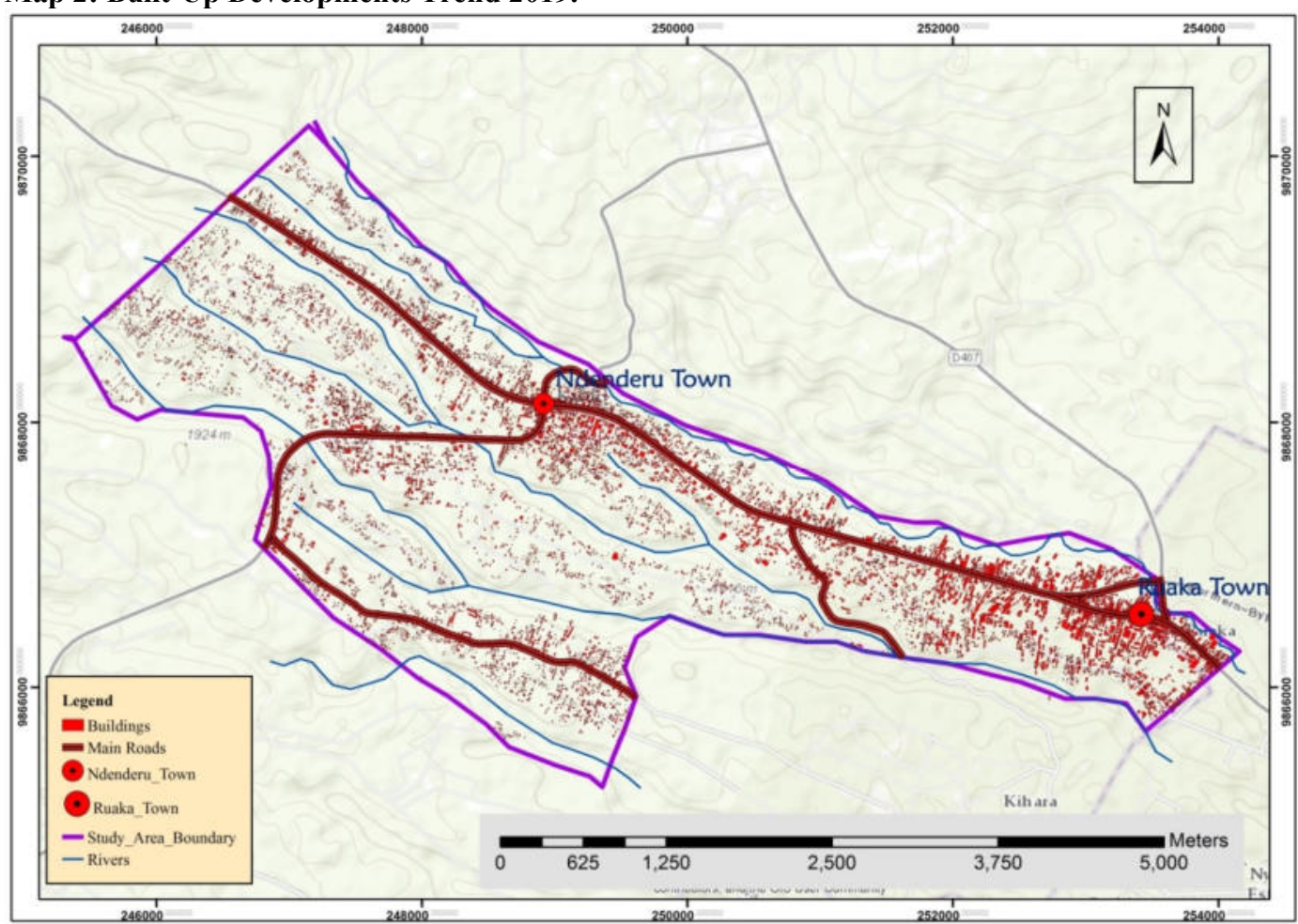

\section{Map 3: Level of Land Subdivisions}

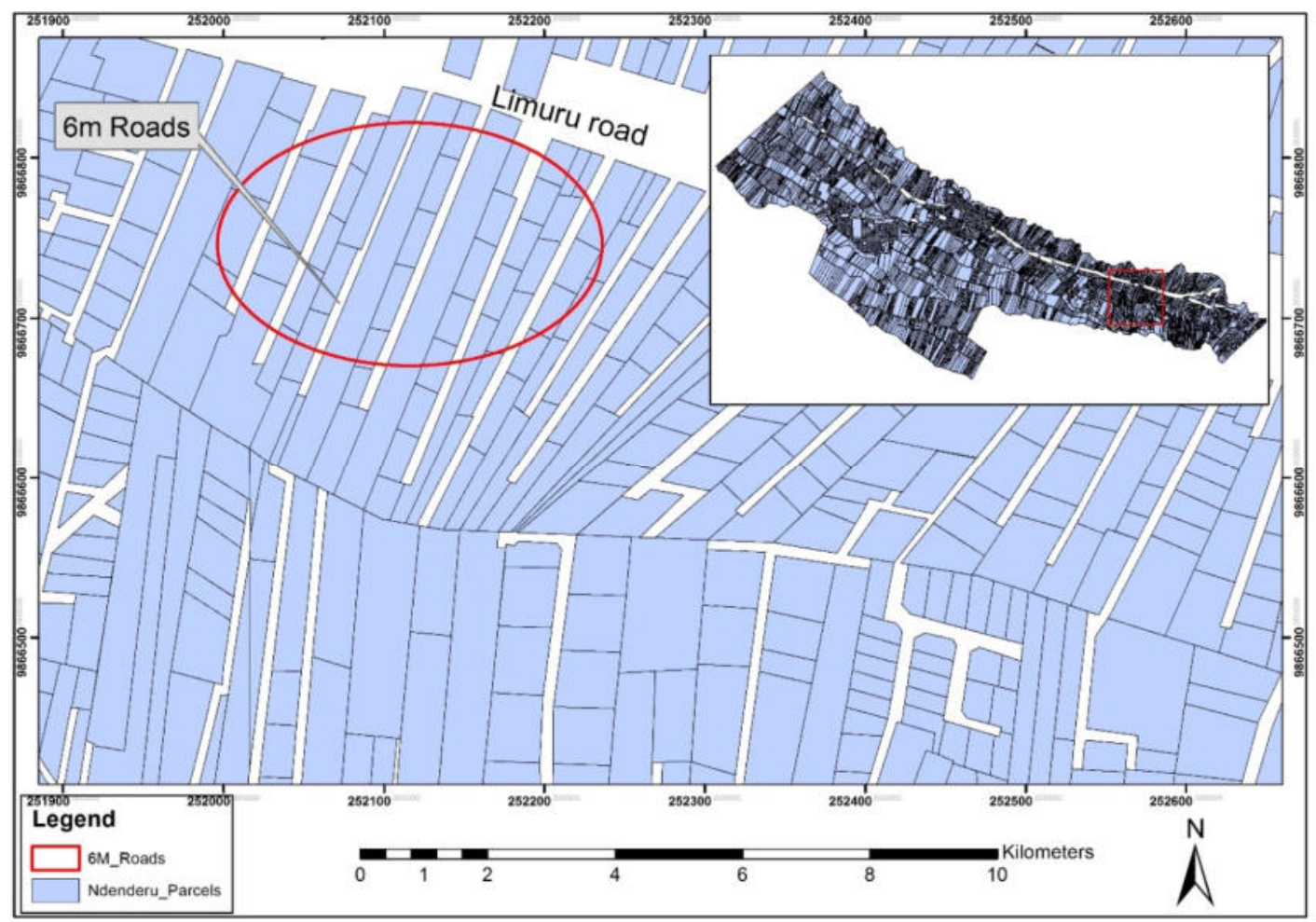

\section{STUDY METHODS}


Quantitative and qualitative techniques of data analysis were used in the study research design. Descriptive design was used in the description of trends and comparisons of data findings to give an accurate and valid representation of the variables. Content analysis of books and journals were used and case studies were used to depict the best practices which were used in making recommendations. The main target elements are urban built-up areas or buildings, vegetation and agriculture land. Other target populations include Ndenderu ward residents, the business community and developers and County Government officials.

The study adopted a random sampling design for the household questionnaires which mainly targeted the residents, business community and developers in Ndenderu Ward. It was essential to formulate a working formula to arrive at the sample size within the study area. In order to get a sampling size, Kothari (2004) [5] formula for finite population size was used to get the right sample size: -

Where $\mathrm{n}=$ Sample size

$$
\mathrm{n}=\frac{Z^{2} \cdot p \cdot q \cdot N}{e^{2}(N-1)+Z^{2} \cdot p \cdot q}
$$

$\mathrm{N}=35,750$ (Population)

$\mathrm{Z}=1.96$ (the value of standard variate at a given confidence level and to be worked out from a table showing area under the normal curve)

$\mathrm{p}=0.5$ (sample population)

$\mathrm{q}=0.5(1-\mathrm{p})$

$\mathrm{e}=0.05$ (given precision rate or acceptable error)

\section{$\mathrm{n}=380.08$ or 380}

$$
\begin{gathered}
\mathrm{n}=\frac{1.96^{2} \cdot 0.5 \cdot 0.5 \cdot 35,750}{0.05^{2}(35,750-1)+1.96^{2} \cdot 0.5 \cdot 0.5} \\
n=\frac{34,334.3}{90.3329}
\end{gathered}
$$

The sampling was based on confidence level and precision rate concerning the population in Ndenderu Ward. Cochran (1967) [10] states $30 \%$ of the population as sufficient for a study. A margin of error of 5\%, confidence level of $95 \%$ and a sample proportion of $50 \%$ was used. A sample size of 380 was selected out of the population of 35,750 of Ndenderu ward as per the 2009 census.

Quantitative data was collected from the County Government by administering the questionnaire and scheduled interviews with sub-county officials. The questionnaire was both closed and open-ended questions to seek in-depth information. Observation checklist and photography were also used in the process of data collection. The secondary data contributed to the formation of background information, needed to build constructively the project and the reader to comprehend the research findings. Sources of secondary data were mainly from a literature review of the existing data and previous studies on land use changes, urban growth, urban sprawl, densification and their impacts on urban infrastructure. Primary data on land use changes were collected through analysis of Landsat imageries for a period between 1988 and 2019. Five remotely sensed data Landsat TM 1988, Landsat Enhanced Thematic Mapper plus ETM+ 1995, Landsat Enhanced Thematic Mapper plus ETM+ 1999, Landsat ETM+ 2010, Landsat OLI \&TIRS 2019 for a period of 30 years were used for the study. The research data that was used for the purpose of this study comprised of Level 1 Landsat images acquired from Resource Centre for Mapping of Resources for Development and in particular Landsat-5 Thematic Mapper (TM), Landsat7 Enhance Thematic Mapper plus (ETM+) and Landsat-8 Operational Land Imager (OLI) and Thematic Infrared Sensor (TIRS) imageries.

The supplementary data was used from google earth imageries and topographical maps were to generate the location maps for the study area. Classification of land uses in the study area was into three categories notably

\begin{tabular}{|c|c|c|c|c|c|c|}
\hline & Data & Sensor & Band & Resolution & Year & Source \\
\hline 1. & Landsat-3 & $\mathrm{TM}$ & $2,3,4 \& 6$ & $30 \mathrm{~m}$ & 1988 & \multirow{6}{*}{$\begin{array}{l}\text { Resource Centre } \\
\text { for Mapping of } \\
\text { Resources for } \\
\text { Development }\end{array}$} \\
\hline 2. & Landsat-5 & ETM+ & $2,3,4 \& 6$ & $30 \mathrm{~m}$ & 1995 & \\
\hline 3. & Landsat-5 & ETM+ & $2,3,4 \& 6$ & $30 \mathrm{~m}$ & 1999 & \\
\hline 4. & Landsat-7 & ETM+ & $2,3,4 \& 6$ & $30 \mathrm{~m}$ & 2010 & \\
\hline \multirow[t]{2}{*}{5.} & \multirow[t]{2}{*}{ Landsat- 8} & OLI & $3,4 \& 5$ & $30 \mathrm{~m}$ & 2019 & \\
\hline & & TIRS & 10 & $100 \mathrm{~m}$ & & \\
\hline
\end{tabular}
vegetation, agriculture and built-up areas.

Table 1: Remotely Sensed Data and Their Characteristics

Scheduled interviews and questionnaires were also administered to residents, the business community, NEMA (National Environment Management Authority), WRA (Water Resource Authority), NCA (National Construction Authority) and County Government of Kiambu officials. This was used to collect information on the rate of land use changes, drivers of land use changes, their effects, challenges, and possible recommendations. This was resourceful in filling gaps identified during the literature review. Observations were used in the process 
of data collection with the aid of a checklist. Photographs were taken to capture the areas of interest to illustrate the scenario on the ground in terms of the problematic and opportunity areas. The main focus was on the drivers, challenges and effects of land use changes.

Landsat imageries were processed in data analysis and interpreted using ArcGIS Desktop 10.3 software. The interpretation scheme adopted was a combination of supervised classification and visual modification. The LULC was estimated using a series of algorithms embedded ESRI ArcGIS software. Mapping was the methodology used for LULC analysis for the period of 1988 to 2019 as discussed below.

Additional collected data were analyzed through descriptive, inferential and cartographical techniques. Household questionnaire data collected was sorted, edited, entered, verified, validated and analyzed by use of SPSS to give a final output in the form of frequencies and charts. The output of data analysis was presented using LULC maps depicting the nature of land use changes over time. Qualitative data was generated from scheduled interview reports, household questionnaires and observation checklist that were categorized in accordance to the study objectives and reported in narrative form to collate quantitative data.

Clearance was sort from the various departments for ethical considerations. Confidentiality and anonymity of data were maintained at all levels during the study period to respect the privacy of all respondents. The research looked at what is permissible to ask so that it doesn't cause any harm to researchers or other subjects and that no lying or deceit was used in getting research information.

\section{FINDINGS AND DISCUSSIONS}

Landsat imageries for the study were classified into three distinct classes namely; vegetation, agricultural and built up areas. Vegetation is represented parcels of land under natural vegetation cover such as trees and shrubs. Vegetation cover is predominant along the riverine and ridges. The land use change over the period of 1988 to 2019 indicates a rapid decline in vegetation cover. Agricultural is the land under farming, bare land and cultivation. Most of these areas have been undergoing rapid decline of agricultural crops farming to built-up areas with massive land use and land cover changes. The built-up areas are areas with buildings including commercial, residential and educational among many others. The land use change over the period of 1988 to 2019 indicates a rapid increase in developments as illustrated in Table 2 and Figure 1 and 2 below. The analysis on decline of vegetation and agriculture with rise in built-up areas is well depicted as illustrated in land use change detection in Map 4 to Map 8 below.

Table 2: Land Use Cover Changes 1988 to 2019

\begin{tabular}{|l|l|l|l|l|l|l|l|l|l|l|}
\hline \multirow{2}{*}{$\begin{array}{l}\text { Land Use / } \\
\text { Year }\end{array}$} & $\begin{array}{l}\text { Area } \\
(\mathrm{Ha})\end{array}$ & $\begin{array}{l}\text { Area } \\
(\%)\end{array}$ & $\begin{array}{l}\text { Area } \\
(\mathrm{Ha})\end{array}$ & $\begin{array}{l}\text { Area } \\
(\%)\end{array}$ & $\begin{array}{l}\text { Area } \\
(\mathrm{Ha})\end{array}$ & $\begin{array}{l}\text { Area } \\
(\%)\end{array}$ & $\begin{array}{l}\text { Area } \\
(\mathrm{Ha})\end{array}$ & $\begin{array}{l}\text { Area } \\
(\%)\end{array}$ & $\begin{array}{l}\text { Area } \\
(\mathrm{Ha})\end{array}$ & $\begin{array}{l}\text { Area } \\
(\%)\end{array}$ \\
\hline Vegetation & 691.47 & 44 & 518.04 & 33 & 479.88 & 30 & 318.51 & 20 & 347.04 & 22 \\
\hline Agriculture & 652.5 & 42 & 706.14 & 45 & 621.54 & 40 & 502.47 & 32 & 382.68 & 24 \\
\hline $\begin{array}{l}\text { Built Up } \\
\text { Areas }\end{array}$ & 224.28 & 14 & 344.07 & 22 & 466.83 & 30 & 747.27 & 48 & 838.53 & 54 \\
\hline Total Area & 1568.25 & 100 & 1568.25 & 100 & 1568.25 & 100 & 1568.25 & 100 & 1568.25 & 100 \\
\hline
\end{tabular}

Figure 1: Land Use Land Cover Changes Trends

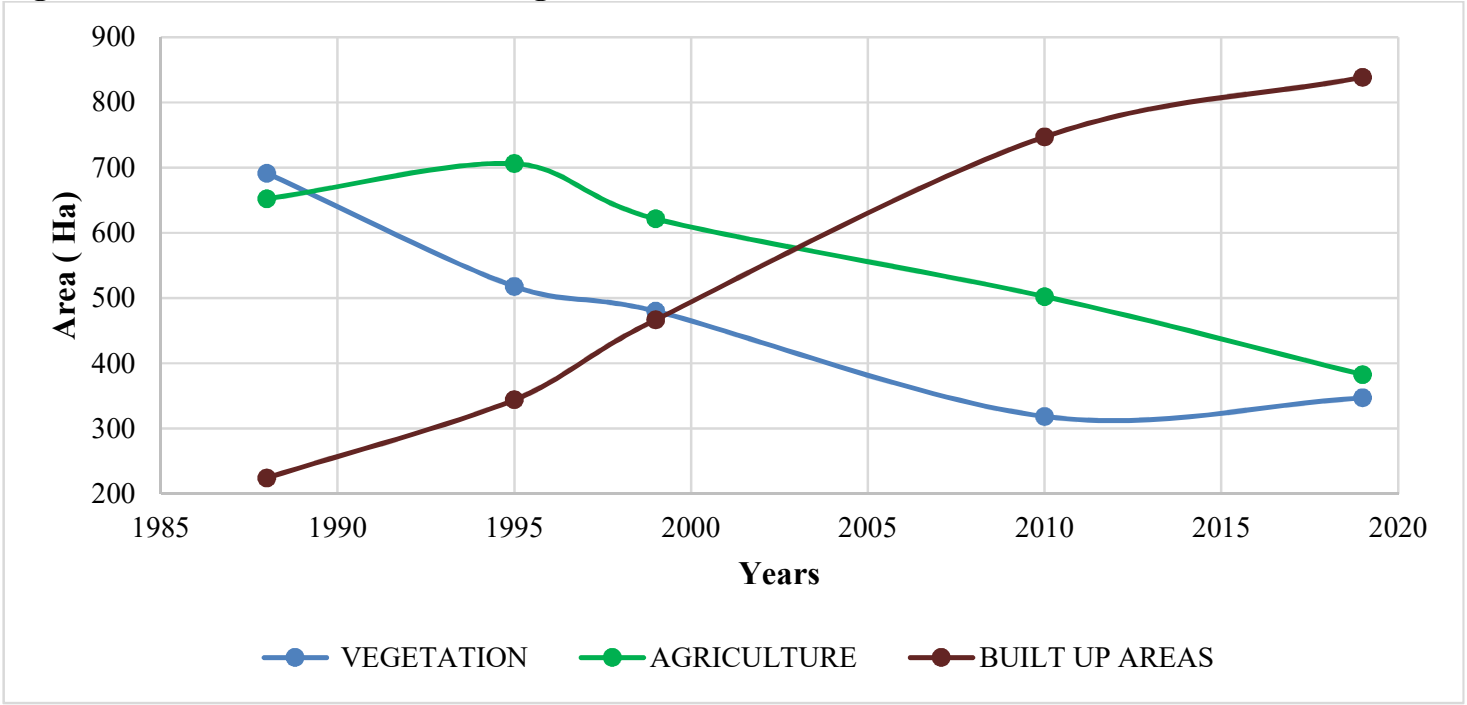


Figure 2: Land Use Land Cover Changes Comparison

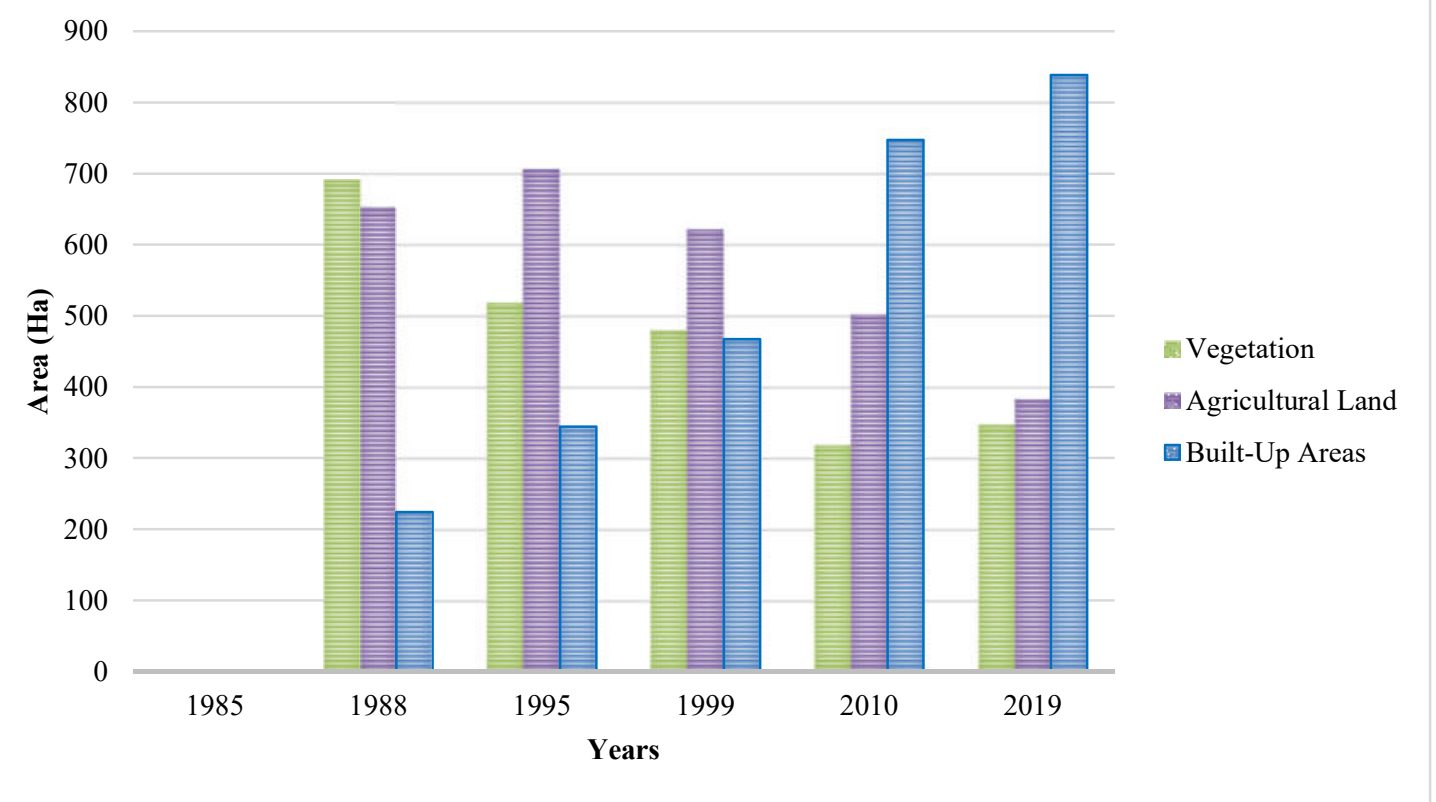

Map 4: Land Use Changes 1988

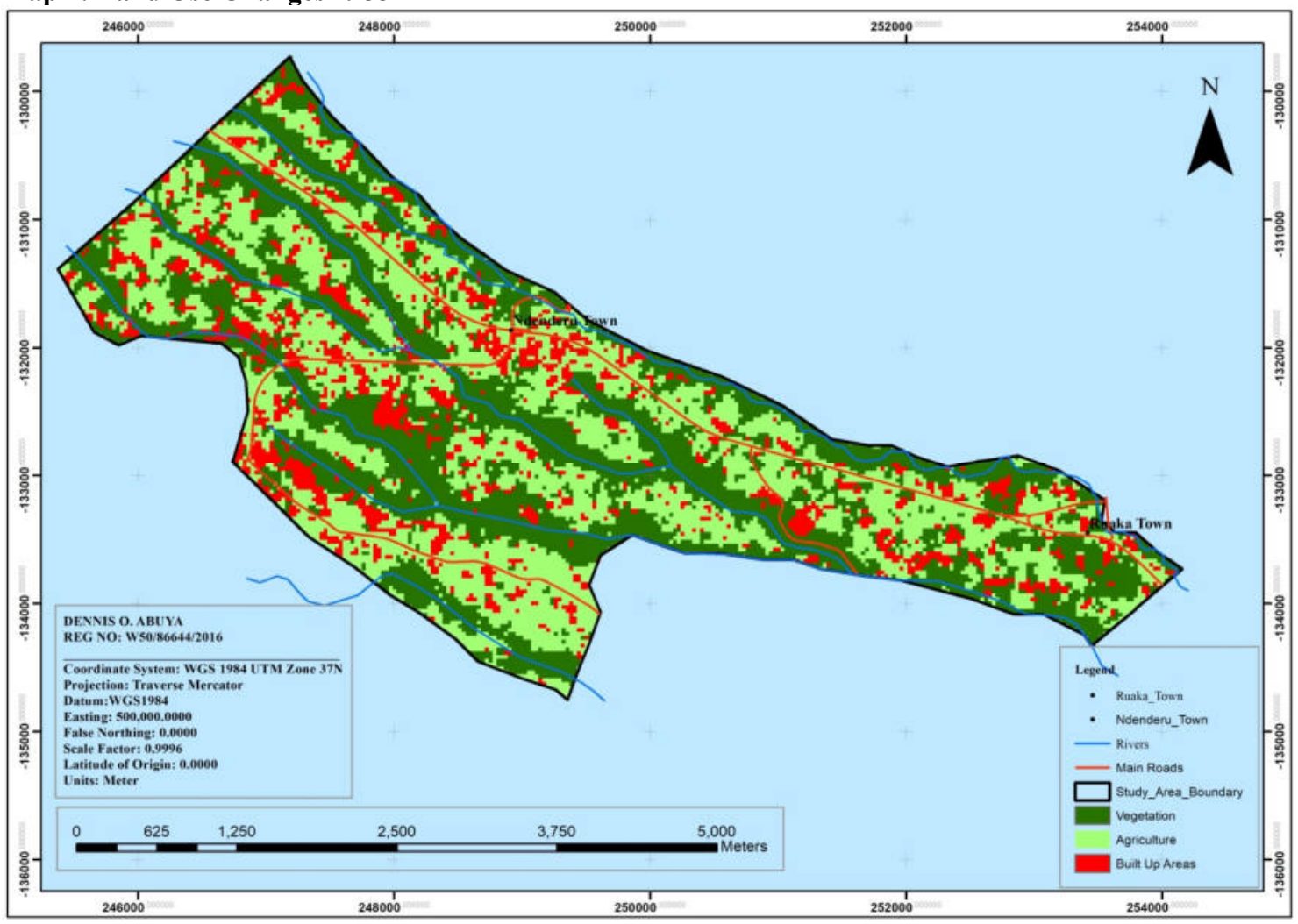




\section{Map 5: Land Use Changes 1995}

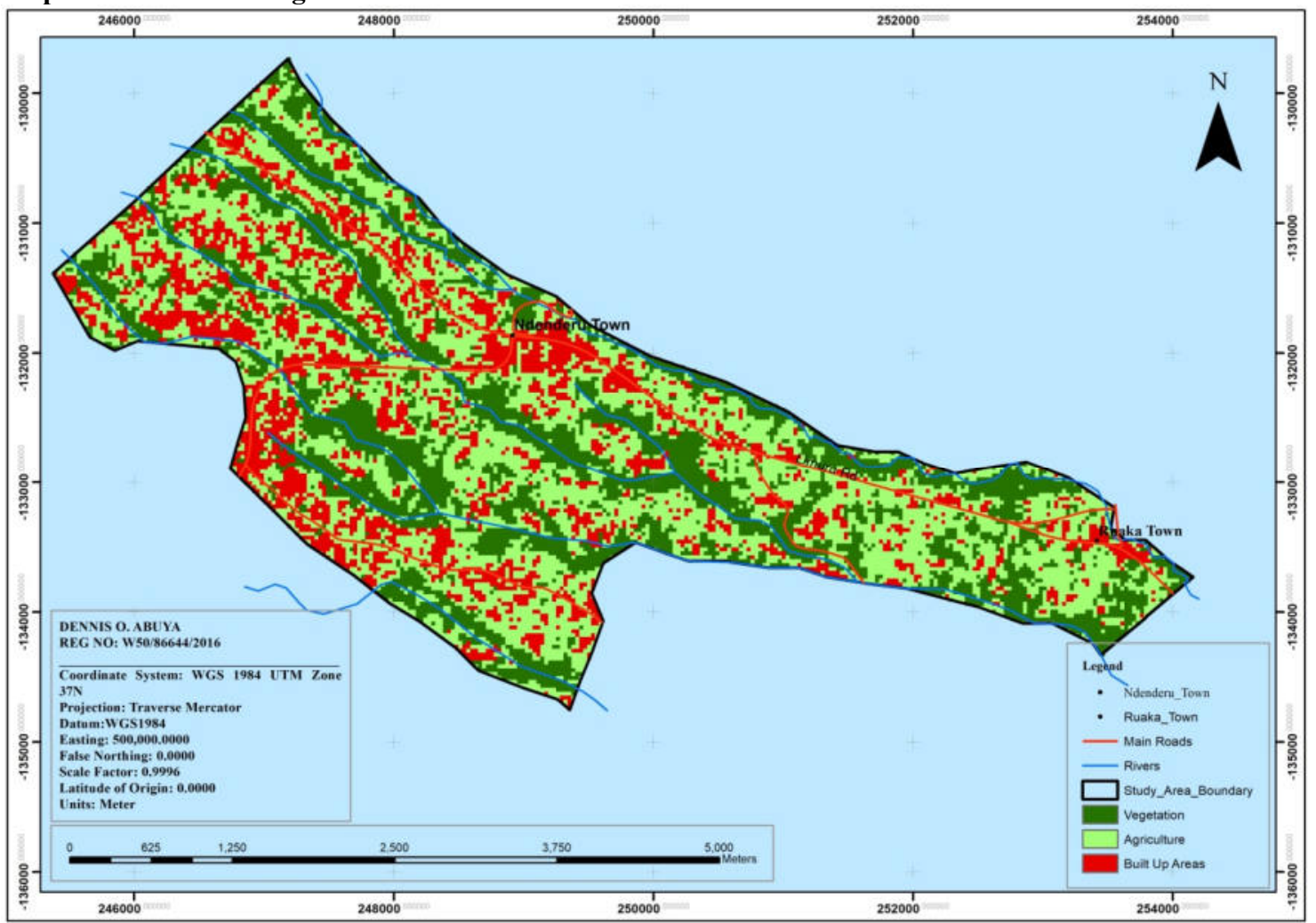

Map 6: Land Use Changes 1999

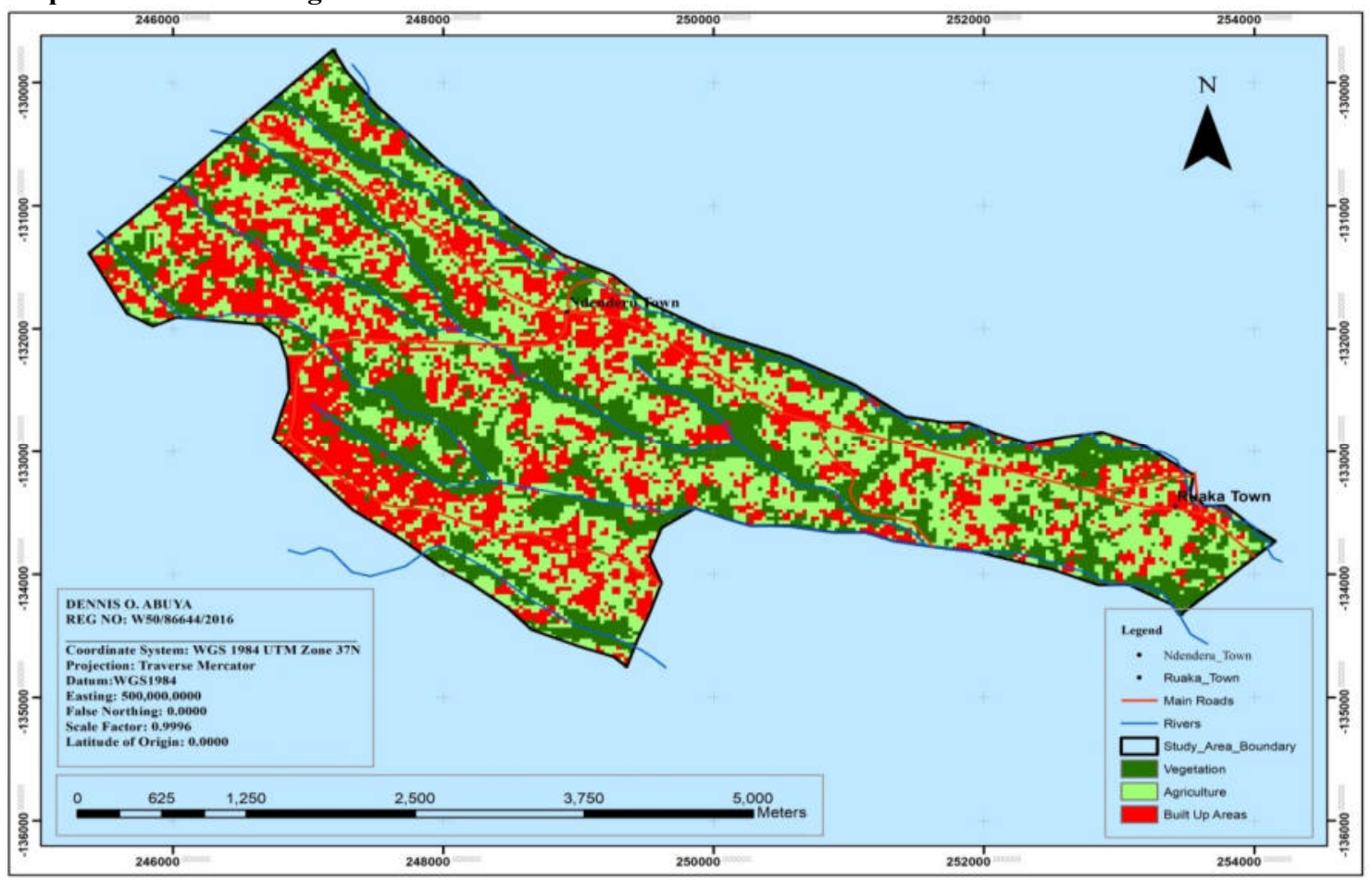


Map 7: Land Use Changes 2010

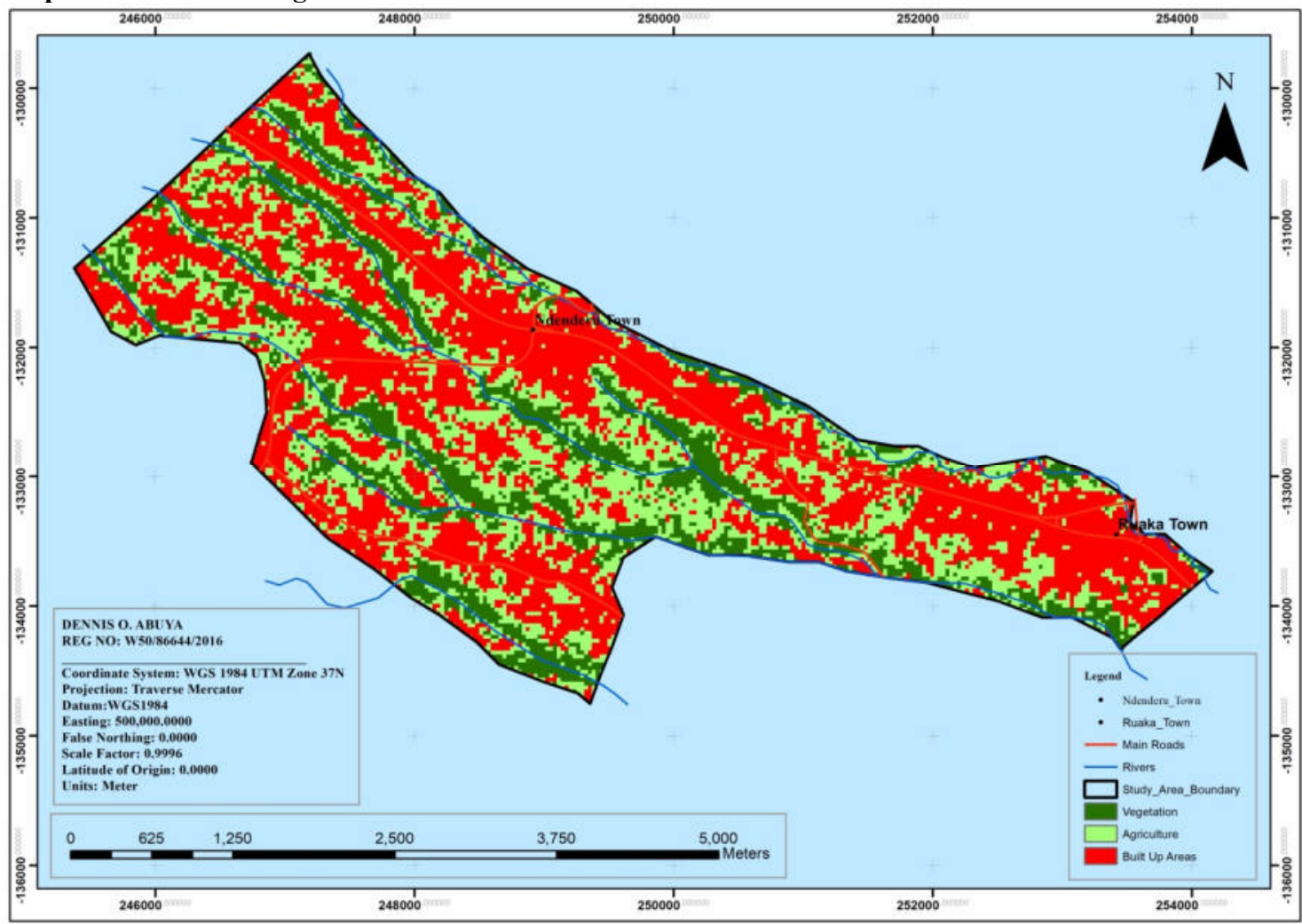

Map 8: Land Use Changes 2019

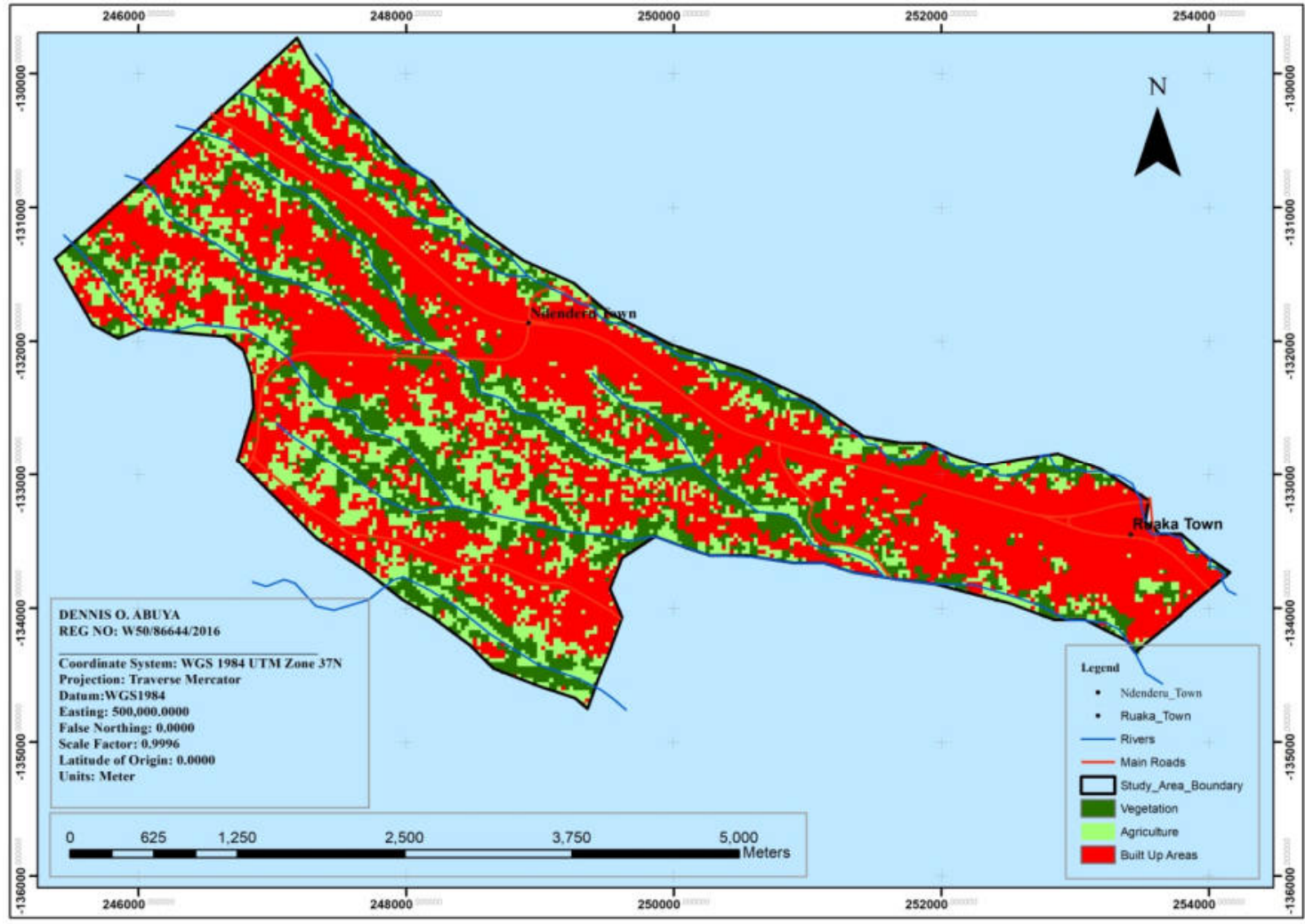


The analysis indicates a steady rise in built-up areas as compared with other previous years and more especially along the major roads where the land is relatively flat. The findings reveal a linear settlement pattern that emerges. The study establishes decline in vegetation and agriculture and rise in built-up areas which are partially contributed by urbanization and population growth in the area with major land fragmentations to smaller plots which have triggered land use conversions to residential and commercial land uses since the plot sizes are not viable for agricultural land use. This is a clear demonstration on how Ndenderu Ward and Ruaka town are experiencing a rise in the rate of land use changes and urban expansions characterized by an urban sprawl towards Limuru and Gachie town. The findings also reveal encroachment of development to vegetation and riparian reserves which expose the human population to disasters and calamities in-cases of climate change. Lack of an approved planning policy has encouraged massive land use changes due to the ad hoc nature of planning using the development control tools which are not documented. This has led to the linear development model with little efforts to provide adequate and efficient urban infrastructure including roads, water and wastewater infrastructure. In addition, the County Government doesn't have enough capacity to enforce development control measures to realize urban development that is commensurate to the available urban infrastructure capacity. Implications of the LUC have led to increased water scarcity and depletion of underground water aquifers as occasioned by low water production from the boreholes. The surface water has been affected since most of the rivers are seasonal. The land use changes have seen massive encroachments of built-up areas to a riparian reserve which has led to declining of the vegetation in the conservation areas. The current traffic congestion experienced is as a result of the land conversions to residential flats which accommodate high population depending on private cars. The high land conversions to residential and commercial developments have led to rising in onsite-liquid waste treatments such as septic tanks which often experience leakages leading to contamination and pollution of water sources.

\section{CONCLUSIONS}

Research findings reveal that increased population growth, market forces, urbanization and close proximity to Nairobi city are the key drivers of land use changes. These drivers have resulted in rapid land use conversions and fragmentation with little efforts to provide commensurate infrastructure to support the increased demand and capacity. The impacts have resulted in narrow roads and unpaved roads without any provision of NMT facilities and storm water drainage management, traffic congestion with increased private car ownership, lack of terminal facilities, increased boreholes, water contamination and encroachment to water reservoirs, use of unconventional onsite treatment methods for liquid waste such as septic tanks as well as weak institutional capacity to manage urban infrastructure. These have effects on the inadequacy of the infrastructure capacity with the growing population. It is therefore important to evolve a management strategy to unravel the adverse effects of the land use changes on urban infrastructure capacity systems notably roads, water supply, and wastewater infrastructure systems to promote land use change-resilient infrastructure and realize sustainable urban growth.

\section{RECOMMENDATIONS}

Sustainable urban infrastructure demands urban management, system efficiency and infrastructure capacity solutions that can address the needs of the communities living in Ruaka. Management of land use changes will address the urban infrastructure capacity challenges and promote land use change-resilient urban infrastructure hence realize the sustainable urban growth in Ruaka Town. Lessons learnt from best practices were used to make recommendations and evolve a management strategy that contains the urban infrastructure capacities.

\section{a. Management of Roads Infrastructure \\ Promoting Transit Oriented Development}

Sustainable transport systems should encourage integration as opposed to segregation of land uses that support Transit Oriented Development. All the areas should be well served with roads and all missing links opened up as illustrated in Map 9 below.

Transit Oriented Development should be supported through encouragement of high-density developments along the Ruaka-Ndenderu transport corridor within walkable distance of 500M to $800 \mathrm{M}$ (Department of the Environment (1973) Circular 82/73) [3] and advocate for mixed-use development in Ruaka and Ndenderu Centres where pedestrian trips can be made to shopping areas and workplaces. Therefore, it's important to have a multimodal integration mixed land use, NMT network, inclusive habitat and optimized densities. 
Map 9: Roads Infrastructure Management Plan

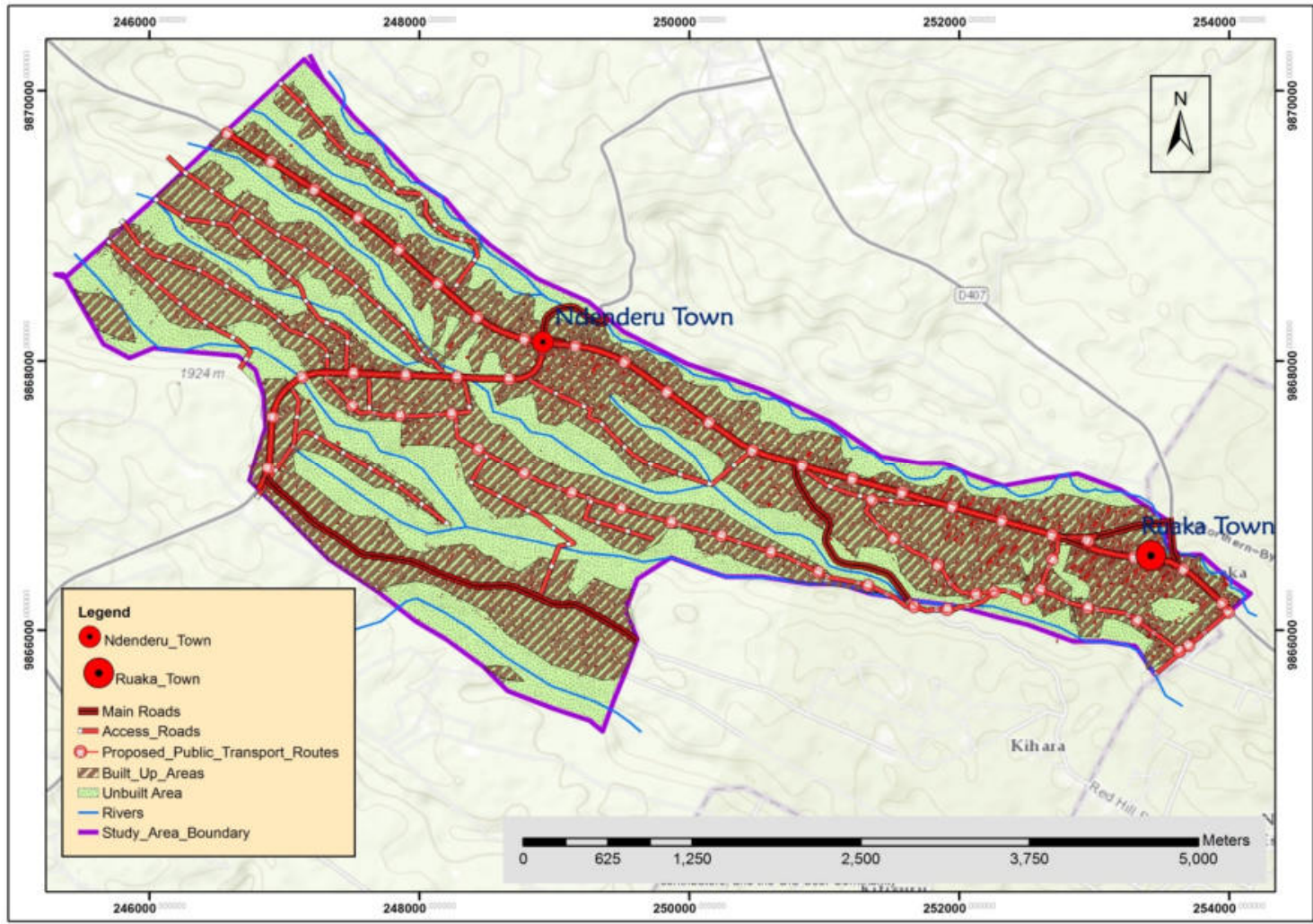

Promotion of Pedestrian and Non-Motorized Transport

There is no great City that you won't enjoy walking in or places you go on vacation are usually areas you can walk in and therefore the element of walkability must be emphasized. Priority should be given to pedestrian and cyclist lanes on every street along Limuru Road and especially within Ndenderu and Ruaka Centres. Walkability and cycling are environmentally friendly and sustainable modes of transport that should be provided after every three blocks and dedication of some routes for purely NMT with short distances to work or business opportunities to embrace social inclusion. Management in Ndenderu ward shall establish such connected walking networks, adequate walkway, path surfaces, the creation of bike lanes and bicycle boulevards enhanced with the use of street furniture and pedestrian-friendly design features, integration of cycling with transit with consideration of pedestrian safety, comfort and convenience. This will be achieved through traffic calming measures such as speed bumps, pedestrian ramps, pedestrian crossings, flyovers, traffic signals, segregated and connected NMT routes. Vibrant urban spaces including street vendors, street furniture with active frontage with transparent buildings facades and public displays has to be provided along Limuru road. Infrastructure and amenities including the revitalization of existing open spaces and sanitation facilities have to be provided for pedestrians and NMT users within the vibrant Ruaka and Ndenderu towns. 
Map 10: Non-Motorized Transport Management Plan

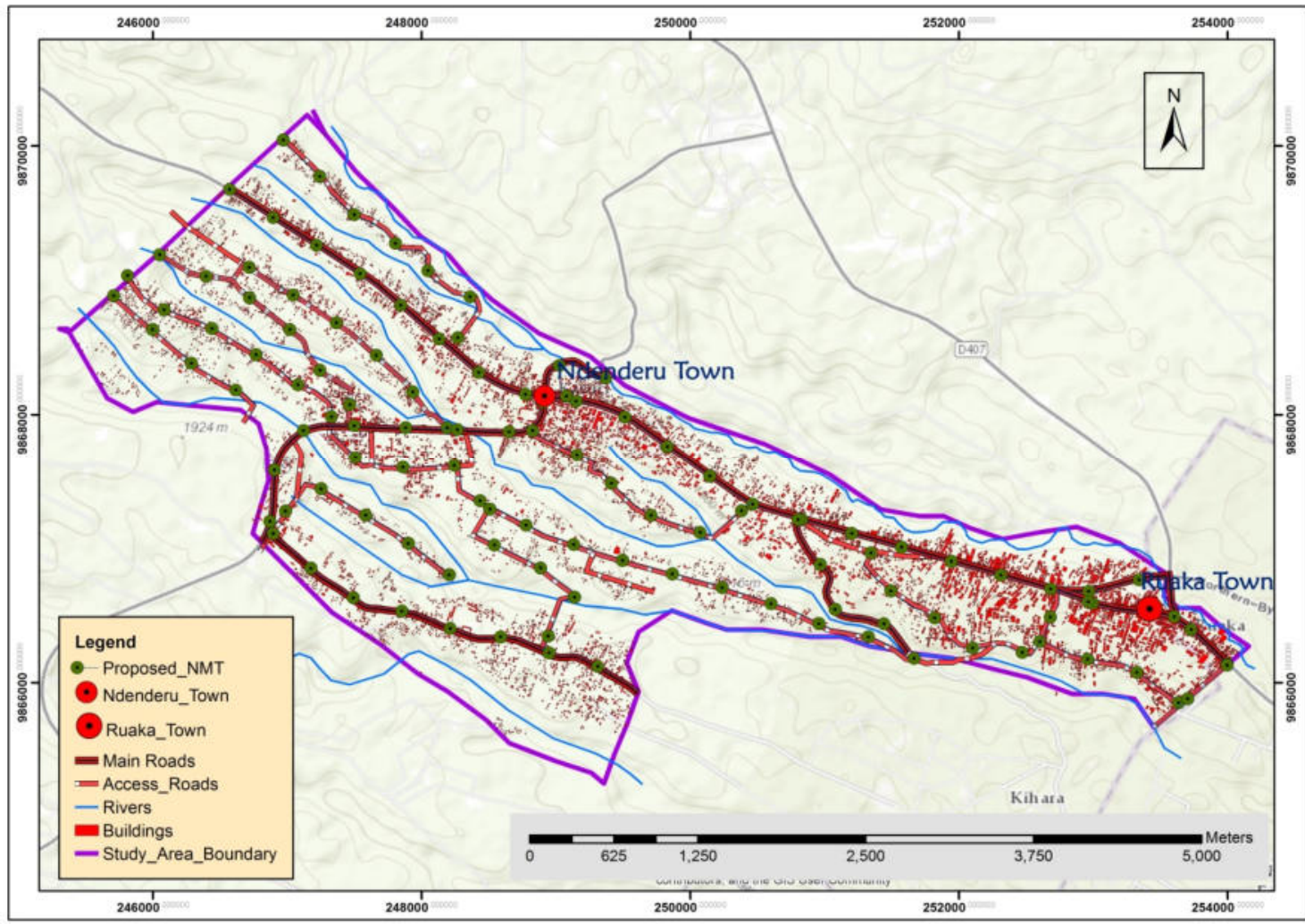

Enhancing Accessibility of All Public Spaces and Streets

All public spaces and streets should be made accessible to all people with mixed-use land use within walkable distances. Secure parking facilities and services for NMT users. Provision of toilets and sanitation facilities shall be emphasized within 500-800M (Department of the Environment (1973) Circular 82/73) [3] radius within terminal facilities. Mobility improvement and road safety should be considered whereby safety means that children and women can feel comfortable on such roads when left alone. Cyclists should be provided with bike lanes and bicycle boulevards. Cycling shall be integrated with transit systems with provisions made for bicycle parking/rickshaw stands with consideration for their safety and security concerns. Improve strategies to transport systems which enhance vehicle efficiency can be achieved through the use of a vehicle and clean fuel technologies that are environmentally friendly and energy efficient, through inspection, maintenance and use of intelligent transport system. Other key interventions to be used include prioritization walking and cycling; encourage the use of more fuel-efficient vehicles, pricing and regulatory mechanisms and enhancement in use of cleaner fuel technologies.

\section{Increasing Accessibility, Connectivity and Network Density}

The need to increase accessibility, connectivity and network density equally enhances the efficiency of transport systems to enhance dispersion of high traffic volume. This shall be done over a network of alternative streets through the provision of the shortest route of pedestrians and NMT users to transit stations and the main RuakaNdenderu Transport Corridor. Understanding the dynamics of transportation being a route used by trucks and matatus and other interaction influences such as travel demand to and from the workplace in Nairobi and provision of alternative routes. Good accessibility of public transport systems by all with the integration of other modes of transport such as walking and cycling in an integrated and seamless manner. Reliability of the availability of public transport (Matatu) affordable to allow passengers to travel whenever they want and that they are assured of their availability with route possibilities, timings, and frequencies. Transport facilities and systems must be acceptable in terms of their comfort, cleanliness, personal safety, reliability and security. Consideration of the connectivity and linkages of the limited capacity of roads that can accommodate the cars along routes such Limuru Road, Western and Northern and how they connect to Kiambu Road.

\section{Enhancing Multi-Modal Integration}

Multi-Modal Integration should be p[romoted to enhance equitable distribution of road space to accommodate all modes of transport and priority being the mass transit systems, seamless physical connectivity of modes of transport to minimize travel time, time of transfers and cost for commuters along the Ruaka Ndenderu Transport 
Corridor through provision of a variety of modes with considerations on safety, comfort, reliability in terms of time and frequencies, affordability and acceptability. The multimodal integrated model will diversify different models of transport which are efficient, comfortable to use, acceptable, affordable and reliable in terms of the frequency and availability. The main emphasis is the provision of mass transit systems such as Bus Rapid Transit, Light Rail Transit and High Occupancy Vehicle (Buses and mini-buses) with dedicated lanes. In addition, the model proposes exclusive Use Lanes (BRT) on Ruaka-Ndenderu Corridor. Dual Carriage facilities shall be encouraged along the major routes with an integrated NMT/Cyclists and walkability to the transit station and the main transport corridor in a seamless manner.

\section{Inducing Modal shift}

Inducing modal shift will trigger the efficiency of the transport systems. Mixed-use development shall be encouraged with the location of homes, workplaces, stations, public facilities within an accessible radius to encourage walking and cycling within the shorter distances. Parking fees shall be increased for private means of transport as well as prohibiting on-street parking.

Placemaking and safety shall be enhanced through the creation of safe, comfortable, vibrant urban spaces, reduction of boundary walls, the building of non-opaque walls with transparency, minimum setbacks to help provide natural surveillance within areas planned for mixed-use development and more especially the commercial areas to encourage walkability while shopping.

\section{Enhancing High Density-Mixed Income Developments}

High density, mixed-income developments should be integrated to maximize densities within TOD to facilitate high population who walk, cycle to access and use public transport. Affordable housing should be promoted within the liveable communities since they are the majority who require public transport, cheap accommodation, and other amenities.

\section{Enhancing Compact Developments}

The new urbanism concept, walkable community concept, and compact town development is recommended to curb urban sprawl and should be promoted to address the rising land use changes that have encouraged urban sprawl and corridor development in Ruaka area. Planning and Management should encourage closer land uses/compact developments and structural form of mixed-use developments are some of the avoid strategies that will encourage walkability, cycling as well as minimize travel trips hence discouraging car ownership which is on the rise in the area. Transit-oriented development that advocates concerns for the city of workers and transit as opposed to the city of cars.

\section{Management and Maintenance of Roads}

Tarmacking or graveling of murrum roads, regular maintenance and repair should be undertaken to control dust and muddy conditions of roads due to weather variations which makes road users uncomfortable to use such roads. Enhance Safety and Security

Safety and security of road users, especially to pedestrians, should be enhanced through measures such as the use of curbs, installation of security lights, footbridges and dedication of NMT and cyclist lanes.

\section{Road Widening Through Surrenders of Part of the Land}

All properties that attract high population densities should be subjected to surrender of part of their land for road widening. This will provide room for other services such as utility provision, NMT and cyclist lanes consideration among many others.

\section{Provision of Alternative Transport Routes}

Some areas that are not served with public transport network should be considered with alternative access routes to enhance the mobility of such corridors. Due to the narrow nature of roads and the high cost of compensation in the process of demolition to pave way for road expansion, some of the access roads can be dedicated as entry points and others exit points exclusively.

\section{Manage Storm Water and Floods}

All stormwater drainage should be directed to the river or green infrastructure or parks to ensure that high percolation to the ground takes place. Public-Private Partnership must be promoted to enhance regular maintenance and management of the drainage way-leaves and channels. Provision should be made for green infrastructure (open spaces, green belts, and parks) to act as resilient measures to floods during rainy seasons with the rise of urban fabric due to land use changes in the area. 
Map 11: Stormwater Management Plan

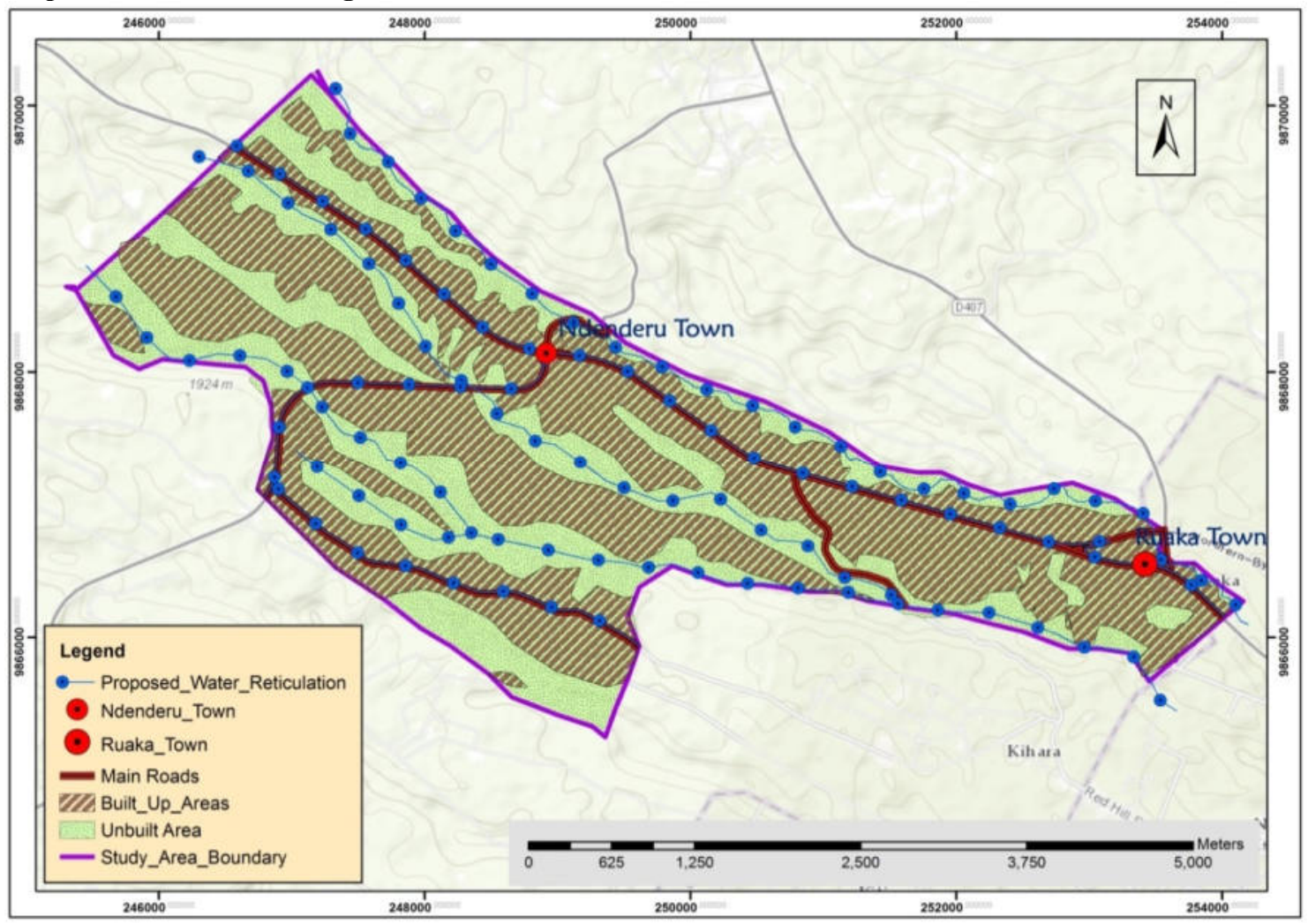

Provision of Bus-Stop and Parking Areas

Provision should be made for a public bus park and parking provisions for the commercial areas within Ruaka town. Parking strategies are essential in the CBD area with proper management and maintenance of parking facilities. Considerations should be made on an understanding of the parking supply and demand position in Ruaka town. Parking strategies to be considered include restriction of on-street parking, parking pricing and off-street parking facilities as well as traffic management strategies and travel demand management strategies.

Zoning, Development Control and Enforcement. Enhance Adherence to Regulations on Subdivisions with Guidelines on Minimum Access Roads

It is essential to provide for zoning regulations to all the land uses and consider their compatibility to adjacent uses, available infrastructure to support such land uses. Besides the compatibility, densities have to be graduated such that there is no gradual shift from high density to low density in terms of the densities, land use classification and level of land subdivision. Compulsory surrender of part of plots for road widening, observation of road hierarchies, enforcement of minimum road sizes, streamline conflicting policies on who is mandated to undertake subdivision and spell out clearly the minimum subdivision sizes-land use planning/zoning.

Environmental Transport Options For Protecting and Conservation of the Environment

It is known all over the world that cities that don't spend much on cars create huge savings and enhance air quality. Environmental transport options of protecting and conserving environment will make urban infrastructure protect us rather than threatens us and therefore should be considered to enhance efficiency and effectiveness of transport systems. These options include improve strategy such as environmental performance to prevent air and noise pollution, charging for any social, environmental and economic impacts, promoting transport modes that are energy efficient, use of more fuel-efficient vehicles, using cleaner fuel technologies, vehicle and clean fuel technology that are environmentally friendly, regular inspection and maintenance of transport system. Other measures include the use of medium-sized vehicles with modern emission controls.

\section{Public Participation and Consultation}

Public participation and consultation should be done with stakeholders for the implementation of any proposals made to enhance the efficiency and effectiveness of roads and transport systems.

Integrated and Enhanced Inter-Agency Coordination and Collaboration in The Management of Road Infrastructure Systems

Coordination and Collaboration in a holistic and integrated manner among institutions should be enhanced to realize the implementation. There is a need for proper coordination with a different organization within the 
different jurisdiction of Nairobi County since transport systems are managed by different institutions such as KeNha, Kerra, KURA, among others. The partnership between different stakeholders is essential to ensure broadbased support to maintain the sanity of neighborhoods through joint ventures/public-private partnerships in the provision of support infrastructures such as street lighting, road widening, stormwater drainage, NMT or pedestrian and cyclist lanes, sewer and water reticulation which the government might take time to provide.

\section{b. Management of Water Supply Infrastructure Capacity}

Land use changes with high population and increased water demand pose great risks to supply of sustainable urban water services which call for a transition towards improved water supply and management with major consideration on making the water supply systems resilient to such land use changes. The following are some of the recommendations to enhance the resilience of urban water supply systems as discussed below.

\section{Water Reticulation/Connection to Nairobi}

An integrated water supply system should be installed with water reticulation serving all properties. The water should be clean and affordable tariffs be provided to the consumers.

Map 12: Water Reticulation Management Plan

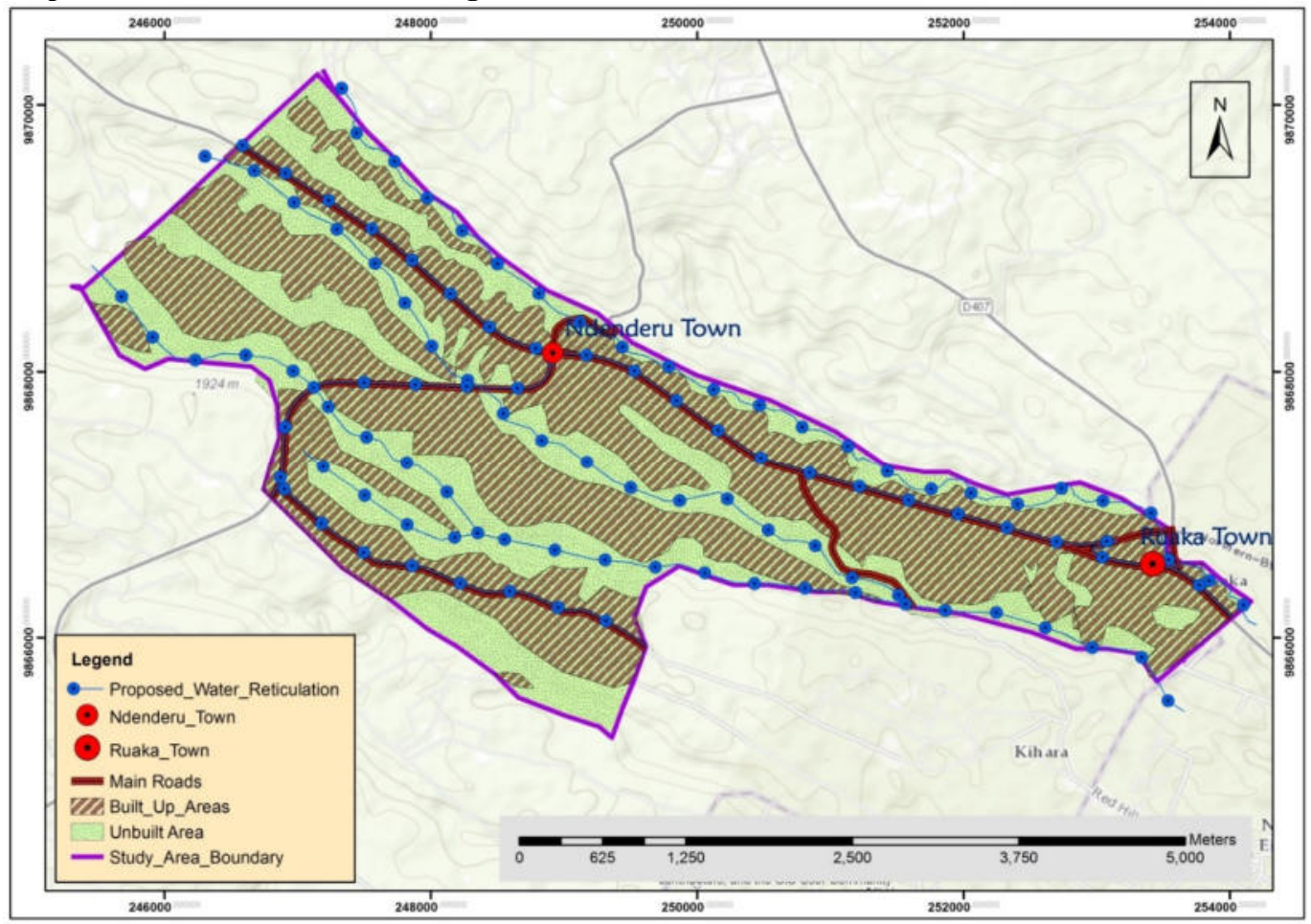

Protection of Conservation Areas and Riparian Reserves/Punitive Measures

Instead of bulldozing, leveling sites and building up to the riparian river reserves, green edges along the riparian reserves should be left as normative with a set of conservation practices within the urban fabric which always gives astounding results.

\section{Control Water Pollution and Contamination}

Developments on riparian reserves should be controlled through strict enforcement and development control measures to control pollution and contamination of Ruaka rivers. Boreholes should be sunk away from areas close to pit latrines. Water from boreholes should at all times be treated before use of its water to minimize the high risk of water-borne diseases. 
Map 13: Conservation and Riparian Reserve Management Plan

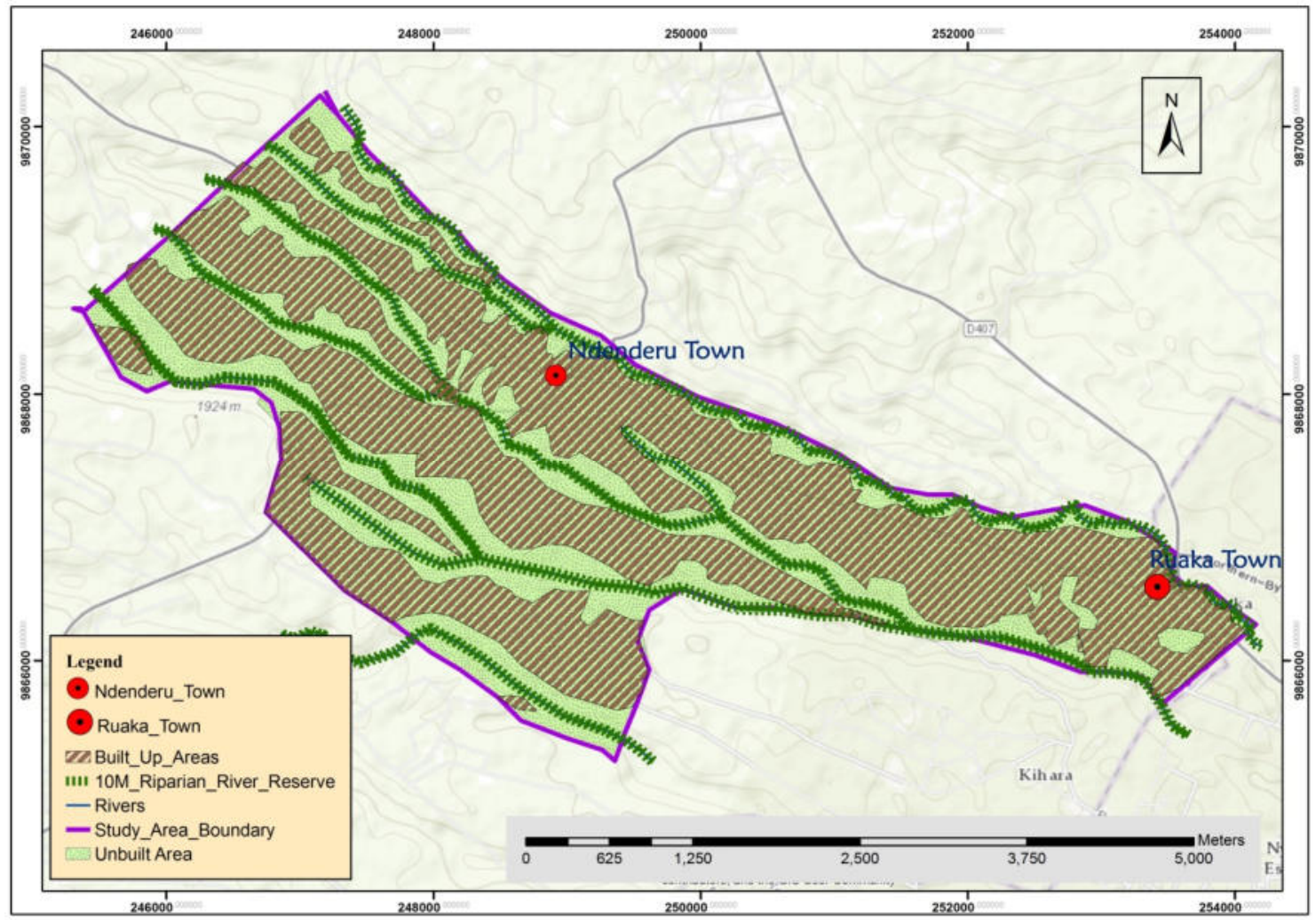

Drill Public Boreholes

Public boreholes should be sunk to supplement water supply especially in areas where there is high demand. This should be treated and spatially distributed for equity in the accessibility of clean water.

Periodic Upgrade, Checkup and Maintenance

Routine checkups, upgrade of water supply infrastructure systems to meet its capacity and maintenance should be done regularly. The drilling of boreholes should be regulated to ensure sustainable exploitation of the resource.

Integrated and Enhanced Inter-Agency Coordination and Collaboration in Management

There should be an integrated, coordinated and collaborated approach of management of water resources by various inter-agencies such as the Karuri Water and Sanitation Company Ltd, Water Resource Authority and National Environment Management Authority in regulation and management of boreholes, riparian reserves, and other water sources.

\section{c. Management of Waterwater Infrastructure Capacity}

\section{Sewer Reticulation Along the Lowest Point to Connect to Nairobi City County}

An integrated conventional sewerage treatment network system be installed in the area with a clear reticulation to serve all properties. This should be along the river reserve being the lowest points. Negotiations should be done with other jurisdictions such as Nairobi City County to allow the sewerage connection to its borders due to its low terrain to ease of connectivity from Ruaka Town.

Preferential Property Treatment to Those That Use Sustainable Wastewater Management

Differential property taxation should be given for those using other sustainable systems of recycling, treatment, and re-use of wastewater should be given over those using septic tanks and pit-latrines. 
Map 14: Sewer Reticulation Management Plan.

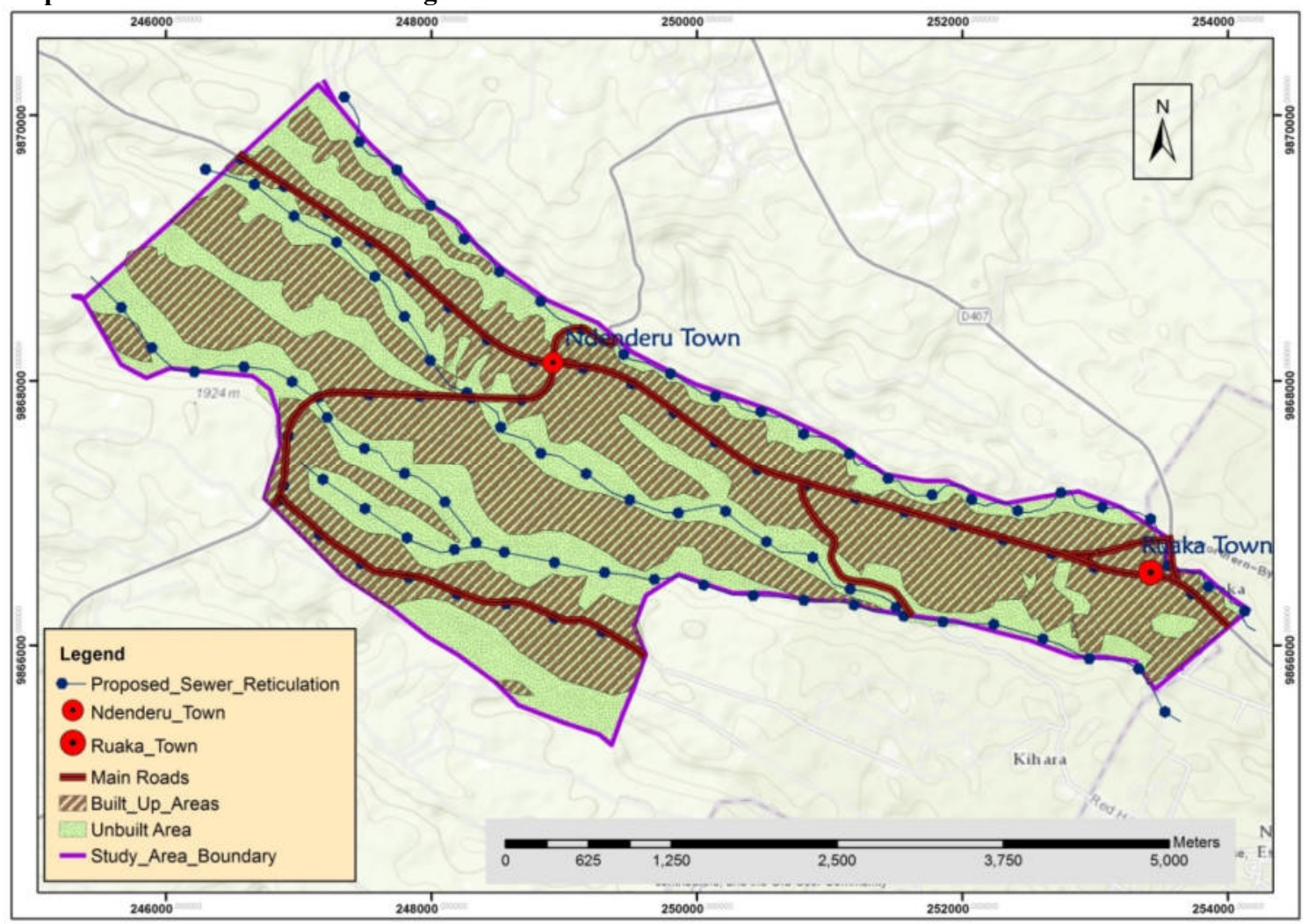

Routine Checkup and Maintenance/Punitive Measures

Regular checkup of wastewater infrastructure should be done to spot instances of leakages and spillages. Punitive measures should be given to those that flout rules by directing their wastewater to rivers and road reserves. Periodic upgrading of the capacity of wastewater infrastructure should be done to meet the expanded capacity of the infrastructure systems.

\section{Regulate and Control Septic Tanks and Pit Latrines}

Wastewater management systems such as the use of pit latrines and septic tanks should be prohibited within Ruaka town. This will reduce the health risks and costs and enhance the sterility of the environment.

Integrated and Enhanced Inter-Agency Coordination and Collaboration in Management

An integrated, coordinated and collaborated system of management of wastewater should exist between the County Government, private developers, and other county governments that border the jurisdiction.

\section{EVOLUTION OF AN URBAN INFRASTRUCTURE MANAGEMENT STRATEGY}

\section{i. Technical Dimension}

Road infrastructures such as Limuru Road and Western Bypass and Northern Bypass within the study area are interconnected within the study area and across the adjoining Nairobi County jurisdictions. Although Limuru Road, Northern Bypass and the proposed Western Bypass have been built in different periods of history, some out of different sizes and conditions such as the Limuru Road with many potholes, there must be a concern of upgrading, repair and interconnection to the areas that are experiencing such rapid land use changes. Interoperability of these roads between takes place across Nairobi County and Kiambu County's jurisdictions platform although they are part of the same Nairobi Metropolitan agglomeration. These roads are of different classes and are of different limited capacity such that the access roads which are very narrow can only accommodate a limited number of cars. It is important that managers introduce single routes which will not be used as dual carriageways within the settlement areas. If uncontrolled and unmanaged, the limited capacity of vehicles might crunch their capacity or bring up snarl-ups. The entire road network should be managed with alternative exit points such that if there is a failure in one end or there is an inefficiency, it doesn't extend to the road network system. The links and interfaces between different roads classes such that of there is an accident at some point of the road, it doesn't affect the rest of the system or interrelated links such as Red-Hill road or other roads leading to different parts. The urban road network systems should be integrated with multi-modal passes. In addition, the coordination should be done by one agency with several transport lines. Management of 
transportation in Ruaka should ensure high-frequency departures which run day and night with regular targeted fare reductions. The management should also ensure that future developments are built around the public transport lines such as Limuru road or within walking distances to public amenities and shopping areas such as Ruaka Square, and Ndenderu shopping centres. Traffic monitoring systems should be installed in Ruaka and Ndenderu areas for the success of the proposed integrated public transport system. The benefits gained from such efficient and integrated transport system shall attract investors, businesses and growth in the economy in Ndenderu Ward. Water resources should have integrated water resource management systems with the diversification of water supply, expanding and building water reservoirs with the current proposed reservoir outside the study area boundary in Muchatha area, management of water demand through pricing, enforcement on water conservation measures, importation of water and desalination of borehole water.

\section{ii. Economic Dimension}

Urban infrastructure in Ruaka Town such as Limuru road, Northern Bypass and Western Bypass are long term investments that require huge sunken costs which might be difficult to recuperate since they are a public good investment for economic development and prosperity of the town. As a result, such investments are not be produced for commercial purposes but as public services which no economical rational enterprise will be willing to provide as they might not be paid for. There is a need for economies of scale so that the costs and infrastructure services along these roads are used optimally. Management of these roads should be done in the most efficient way with minimal wastes. Road cutting, alteration and any other unauthorized modifications should be minimized. There are instances where private developers cut the roads without reinstating their status to the original state and this should be controlled. Management should also be tagged on profitability to ensure infrastructure services provided are profitable to develop further services and therefore they should generate profit to invest in better technologies to better treat the roads through maintenance or repairs. Subsidies received from some of these infrastructure services should be utilized in a better way.

Ruaka town should use a progressive water tariff structure that penalizes the inefficient use of water for domestic water consumption that exceeds $40 \mathrm{~m}^{3}$ per month for residential areas to ensure better utilization of water resources. The water management companies should undertake regular monitoring of water infrastructure to ensure the maintenance of existing water supply infrastructure as opposed to building more or expanding the infrastructure. The management of urban infrastructure should ensure earlier identification of aging infrastructure or approaching the end of the design life and retrofit it or build new resilient urban infrastructure. The high rate of monitoring to increase detection in rates and areas of blockages to ensure that they are accurately registered. Water management companies should use modern technologies such as the water pressure management technology in the management of its water resource through Public-Private Partnership. The advanced water pressure reduction installation plant reduces the water pressure during the off-peak hours and at night which reduces leakages. This reduces the amount of water wastage significantly.

\section{iii. Environmental Dimension}

Ruaka town and the entire Ndenderu ward being an urban area is a big polluter from the waste generated from the households and commercial areas. Management of waste infrastructure should be done in the least polluting way through the use of technology such renewable approaches, introduction and connection of sewerage system to the entire ward as opposed to the current unsustainable septic tanks. There is a need to identify assets likely to suffer in case of future urban expansions and other vulnerabilities and provide solutions to curb such menaces. Management of roads and transport infrastructure should create solutions which enhance environmental conservation, reduce emissions and pollutions such as the use of non-motorized transport and pedestrianization of some of the streets in Ndenderu ward.

\section{iv. Social Dimension}

Water tariffs should be provided in a socially equitable way through social tariffs which are favourable to the customers across all social classes. Water is a basic right, it should be provided at an affordable cost where affordability should be relative to the income levels of the people in the area. This should be done in a way that they don't end up spending all their income on water and transportation. Water supply should be developed and supplied to the entire Ndenderu ward without discrimination other sections of the ward. Currently, the water supply infrastructure is only done within the Ruaka CBD area and the rich suburbs where the residents may have the capacity and voice to control or protest decisions of failure to supply of water. Community boreholes accessed by the residents should be constructed to supplement the current water supply. It is vital to use non-discriminating approaches in the provision of urban infrastructure. Infrastructure provision such as the roads, sewer and water reticulation should have high service coverage of the entire ward. There is a need to involve the public in the implementation of all infrastructure projects for public acceptance and confidence through a public engagement campaign to educate the public on the stringent process of infrastructure production. This enables them to know how to maintain such infrastructure such as the roads, water reticulation networks and how to maintain water safety for drinking. The transportation and roads management system should be able to address the social needs by making transportation and road networks accessible, safe and secure and should be carried out in an equitable 
manner to accommodate the disadvantaged groups such as the people with disabilities, women and children. This can be achieved through multimodal transport that focuses mainly on non-motorized means of transport which encourages social groups and interaction with the presence of street furniture, safe public spaces and conducive environment. Streets in Ndenderu ward should be redesigned to regulate and encourage low-speed limits to encourage the non-motorized means of transport and pedestrian use hence enhancing the safety of such road users within Ruaka and Ndenderu towns.

\section{v. Jurisdictional Dimension}

Political factors have influenced LUC especially on policy matters and particularly on zoning regulations which have been changing over different political regimes and hence affect the decisions made on the nature of developments, plot rations and ground coverages used in approval and implementation of plans in Ruaka and Ndenderu Ward in specific. Operation of Limuru Road, Western Bypass, Northern Bypass, and Water Supply systems in Ruaka is across political and legal jurisdictions of National Government, Nairobi County and Kiambu County which poses technical challenges of interconnectivity and interoperability. There is a demand for more reliability of the water supply, maintenance of the Limuru Road which has many potholes. There is a need for coordination and collaboration between the National Government agencies including KURA, KeRRA, KeNHA and Kiambu County. Therefore, Ruaka urban infrastructure management systems can only be successful through urban management strategies, institutional reforms and sound urban governance through political and government commitment to infrastructure projects. Strong political will and effective regulatory and legislative frameworks should be put in place to enhance strict enforcement of the legislation, ensure proper management of roads, water supply and wastewater infrastructure. It is also essential to ensure there are collaboration and sensitization of its stakeholders to enhance transparency and accountability of the projects and programmes in place.

Implementation Strategy

The implementation of the plan shall be as done as provided in the implementation matrix Table 3 Below.

Table 3: Implementation Matrix

\begin{tabular}{|c|c|c|c|c|}
\hline Sector & Short Term (0-2 Years) & $\begin{array}{l}\text { Medium Term (3-5 } \\
\text { Years) }\end{array}$ & $\begin{array}{l}\text { Long Term (5- } \\
10 \text { Years) }\end{array}$ & Actors \\
\hline $\begin{array}{l}\text { Roads } \\
\text { Infrastructure }\end{array}$ & $\begin{array}{l}\text { Street Lighting } \\
\text { Installation of traffic monitoring } \\
\text { systems } \\
\text { Restrict traffic speed within } \\
\text { residential areas } \\
\text { Frequent maintenance rather } \\
\text { than new constructions } \\
\text { Paving the major access roads } \\
\text { Dedicate cyclists and pedestrian } \\
\text { lanes } \\
\text { Surrender of roads for widening } \\
\text { by properties with narrow access } \\
\text { roads within the CBD areas } \\
\text { Management strategy on } \\
\text { coordination and collaboration } \\
\text { in operations } \\
\text { Make all roads infrastructure } \\
\text { projects a priority } \\
\text { Alternative routes optimization } \\
\text { Improved Governance }\end{array}$ & $\begin{array}{l}\text { Opening up missing } \\
\text { links } \\
\text { Upgrading of } \\
\text { alternative public } \\
\text { transport routes } \\
\text { Provide a safe } \\
\text { infrastructure for all } \\
\text { road users at Ruaka } \\
\text { e.g pedestrian } \\
\text { crossings } \\
\text { Public-Private } \\
\text { Partnerships }\end{array}$ & $\begin{array}{l}\text { Tarmacking all } \\
\text { unpaved roads } \\
\text { Road widening } \\
\text { in the entire } \\
\text { ward } \\
\text { Design safer } \\
\text { intersections } \\
\text { and roads with } \\
\text { interchanges at } \\
\text { Ruaka } \\
\text { Provide better } \\
\text { and safer } \\
\text { public } \\
\text { transport } \\
\text { Setting Out } \\
\text { effective } \\
\text { monitoring and } \\
\text { evaluation } \\
\text { systems } \\
\text { The integrated } \\
\text { inter-modal } \\
\text { transport } \\
\text { system }\end{array}$ & $\begin{array}{l}\text { County } \\
\text { Government } \\
\text { of Kiambu } \\
\text { Kerra } \\
\text { KURA } \\
\text { KeNha } \\
\text { Municipalities }\end{array}$ \\
\hline $\begin{array}{l}\text { Water } \\
\text { Infrastructure }\end{array}$ & $\begin{array}{l}\text { Home owner awareness on } \\
\text { system maintenance and } \\
\text { inspection through signing } \\
\text { contracts } \\
\text { Inspection and regulation of } \\
\text { boreholes and pollution to water } \\
\text { sources } \\
\text { Decentralization of water }\end{array}$ & $\begin{array}{l}\text { Sinking community } \\
\text { boreholes at } \\
\text { strategic locations } \\
\text { Increasing the } \\
\text { commercial water } \\
\text { tariffs and } \\
\text { residential flats with } \\
\text { higher plot ratios. }\end{array}$ & $\begin{array}{l}\text { Water } \\
\text { reticulation to } \\
\text { the entire ward } \\
\text { Build Water } \\
\text { Reservoirs } \\
\text { Build a Water } \\
\text { desalination } \\
\text { plant }\end{array}$ & $\begin{array}{l}\text { Karuri Water } \\
\text { and Sanitation } \\
\text { Company Ltd } \\
\text { Municipalities }\end{array}$ \\
\hline
\end{tabular}




\begin{tabular}{|c|c|c|c|c|}
\hline & $\begin{array}{l}\text { management systems } \\
\text { Place people in charge to run the } \\
\text { infrastructure based on their } \\
\text { merits/people suited to do run } \\
\text { projects } \\
\text { Regulation of water } \\
\text { consumption that exceeds } 40 \mathrm{M}^{3} \\
\text { per month and subsidizes water } \\
\text { use between } 20 \mathrm{~m}^{3} \text { to } 30 \mathrm{~m}^{3} \text { per } \\
\text { month. } \\
\text { Management strategy on } \\
\text { coordination and collaboration } \\
\text { in operations } \\
\text { Use of water pressure } \\
\text { management technology in the } \\
\text { management of its water } \\
\text { resource to regulate pressure } \\
\text { during off-peak hours and at } \\
\text { night } \\
\text { Make all water infrastructure } \\
\text { projects a priority } \\
\text { Issue permits for installation and } \\
\text { repairs } \\
\text { Improved Governance }\end{array}$ & $\begin{array}{l}\text { Regulation of } \\
\text { underground water } \\
\text { extraction to avoid } \\
\text { its depletion } \\
\text { Provision of } \\
\text { subsidies to water } \\
\text { and wastewater } \\
\text { management } \\
\text { providers } \\
\text { Enhancing the } \\
\text { autonomy of service } \\
\text { providers. } \\
\text { Public-Private } \\
\text { Partnerships } \\
\text { Minimize operating } \\
\text { costs } \\
\text { Sustain water flow } \\
\text { in areas of } \\
\text { vandalism or illegal } \\
\text { connections }\end{array}$ & $\begin{array}{l}\text { Setting Out } \\
\text { effective } \\
\text { monitoring and } \\
\text { evaluation } \\
\text { systems } \\
\text { Integrated } \\
\text { Water } \\
\text { Mangement } \\
\text { System }\end{array}$ & \\
\hline $\begin{array}{l}\text { Waste Water } \\
\text { Infrastructure }\end{array}$ & $\begin{array}{l}\text { High level of inspection and } \\
\text { enforcement in construction and } \\
\text { management of septic tanks } \\
\text { Management strategy on } \\
\text { coordination and collaboration } \\
\text { in operations } \\
\text { Make all waste water } \\
\text { infrastructure projects a priority } \\
\text { Controlled discharges of raw } \\
\text { domestic wastewater to roads } \\
\text { and rivers } \\
\text { Improved Governance }\end{array}$ & $\begin{array}{l}\text { Increase in charges } \\
\text { for residential } \\
\text { apartments with } \\
\text { higher plot ratios } \\
\text { using septic tanks. } \\
\text { Public-Private } \\
\text { Partnerships }\end{array}$ & $\begin{array}{l}\text { Sewer } \\
\text { reticulation to } \\
\text { the entire ward } \\
\text { Setting Out } \\
\text { effective } \\
\text { monitoring and } \\
\text { evaluation } \\
\text { systems } \\
\text { Integrated } \\
\text { Liquid Waste } \\
\text { Management } \\
\text { System }\end{array}$ & $\begin{array}{l}\text { Karuri Water } \\
\text { and Sanitation } \\
\text { Company Ltd } \\
\text { Municipalities }\end{array}$ \\
\hline
\end{tabular}

\section{REFERENCES}

1. Chiplunkar, A., Seetharam, K. and Tan, C.K (2012). Good Practices in Urban Water Management. Decoding Good Practices for a Successful Future. Asian Development Bank and National University of Singapore. Mandaluyong City, Philippines.

2. Cohen J (1968). Weighted Kappa: Nominal Scale Agreement with Provision for Scaled Disagreement or Partial Credit. Psychological Bulletin 70:213-220

3. Department of the Environment (1973) Circular 82/73: Bus Operation in Residential and Industrial Areas, HMSO, London.

4. Kenawy E, Osman T and Alshamndy A (2017). "What Are the Main Challenges Impeding Implementation of The Spatial Plans in Egypt Using Ecotourism Development as An Example?". Journal of Social Sciences.

5. Kothari, C. R (2004). Research Methodology: Methods and Techniques ( $2^{\text {nd }}$ Edition). New Delhi: New Age International (P) Ltd.

6. Lambin E.F, Turner B.L, Geist H.J, Agbola S.B, Angelsen A, Bruce J.W, Coomes O.T, Dirzo R., Fischer G, Folke C, George P.S, Homewood K, Imbernon J, Leemans R, Li X., Moran E.F, Mortmore M, Ramahkrishnan P.S, Richards J.F, Skanes H, Steffen W. Stone G.D, Svedin U, Veldkamp T.A, Vogel C and Xu J (2001). The Causes of Land Use and Land Cover Change: Moving Beyond the Myths. Journal on Global Environmental Change.

7. Lo C.P and Yang X. (2002). Drivers of Land Use/Land Cover Changes and Dynamic Modelling for the Atlanta, Georgia Metropolitan Area. American Society of Photogrammetry and Remote Sensing. Vol 68. No. 10, October 2002, pp.1073-1082.

8. Reis S. (2008). Analyzing Land Use/Land Cover Changes Using Remote Sensing and GIS In Rize, NorthEast Turkey. Aksaray University/Sensors. 
9. Screenivasulu G, Jayaraju N, Kumar M.P and Prasad T.L (2013). An Analysis on Land Use and Land Cover Changes Using Remote Sensing and GIS, A Case Study in and Around Vempalli, Kadapa District Andhra Pradesh District, India. International Journal of Scientific Research and Publications Vol. 3. ISSN 2250-3153.

10. Snedecor, G.W. and Cochran, W.G. (1967). Statistical Methods. 6th Edition. Oxford and IBH, New Delhi, 381.

11. UNDP (2016): Sustainable Urbanization Strategy: UNDP's Support to Sustainable, Inclusive and Resilient Cities in the Developing World.

12. UN-Habitat (2018). The State of African Cities 2018: The Geography of African Investment. UN-HABITAT. 